\title{
Gig Ekonomisi Bağlamında İş İlişkisinin Değişen Yüzü: Uber Örneği*
}

\author{
ORCID: 0000-0001-9819-1703
}

Ömer ÜNAL ${ }^{* *}$

Hasan Ejder TEMİZ ${ }^{* *}$

ORCID: 0000-0002-2020-3193

DOI: $10.54752 /$ ct.1060793

Öz: Gig ekonomisi, bireylerin, kısa süreli işler bulmak ve gerçekleştirmek için uygulamalara ve/veya internet sitelerine erişim sağlayarak tamamladığ ve genellikle üç tarafin bulunduğu bir iş ilişkisini ifade etmektedir. Gig ekonomisi, hem işin niteliğinden dolayı, hem de işin gerçekleştirildiği mekân kısıtı nedeniyle talep üzerine çalışma ve çevrimiçi çalışma olarak iki alt başlık altında sınıflandırılmaktadır. Gig ekonomisinde meydana gelen iş iliş̧kisinin eşit sonuçlar doğurmadığı bilinmektedir. Platformların kendilerini arz ile talebi buluşturan aracı, işçileri bağımsız yükleniciler olarak sınıflandırması pek çok sorunun ortaya çımasında başlıca nedeni oluşturmaktadır. Üstelik gig ekonomisinin hızlı ve düzenlenmeden büyümesi konunun incelenmesini gerekli kılmaktadır. Bu doğrultuda, çalışmada öncelikli olarak, gig ekonomisi kavramı açıklanmış, kavrama yönelik gerçekleştirilen tartışmalara ve iş ilişkilerinde yarattığ 1 dönüşüme yer verilmiştir. İkinci olarak, gig ekonomisi güvencesiz istihdam bağlamında değerlendirilmiştir. Ardından, gig ekonomisi içerisinde yer alan ve kişisel yolcu taşımacilığ alanında hizmet veren Uber incelenmiştir. Uber'in çalışma hayatı bağlamında olumlu ve olumsuz yönleri ortaya konulmaya çalışılmış, iş ilişkileri, sürücülerin sınıflandırma sorununa yönelik hukuksal mücadeleleri, sendikalaşma girişimleri ve grev uygulamaları detaylı biçimde değerlendirilmiştir.

Anahtar Kelimeler: Gig Ekonomisi, Uber, güvencesizlik, Algoritma, Teknoloji

\footnotetext{
* Bu çalışma, Prof.Dr. Hasan Ejder TEMIZZ’in danışmanlığında Mersin Üniversitesi Sosyal Bilimler Enstitüsü Çalışma Ekonomisi ve Endüstri İlişkileri Anabilim Dalında Ömer ÜNAL tarafindan hazırlanmakta olan "Gig Ekonomisinin Çalışma İlişkilerine Etkisi”" başlıklı yüksek lisans tezinden türetilmiştir.

** Mersin Üniversitesi, SBE, Çalışma Ekonomisi ve Endüstri İlişkileri Anabilim Dalı, Yüksek Lisans Öğrencisi, omerunal1925@gmail.com

*** Prof.Dr., Mersin Üniversitesi, İktisadi ve İdari Bilimler Fakültesi, Çalışma Ekonomisi ve Endüstri İlişkileri Bölümü,

Makale Geliş Tarihi: 14.07.2021 - Makale Kabul Tarihi: 03.12.2021
} 


\section{The Changing Face of Labor Relations in the Context of the Gig Economy: The Case of Uber}

Abstract: The gig economy describes a business model, usually threesided, in which individuals complete by accessing applications and/or websites to find and perform short-term jobs. The gig economy is classified under two subheadings as on-demand work and online work, both due to the nature of the work and limitation of the place where the work is carried out. It is known that the employment relationship that occurs in the gig economy does not produce equal results. The main reason of many problems is that the platforms classify themselves as intermediaries that bring supply and demand together, and workers as independent contractors. Moreover, the rapid and unregulated growth of the gig economy makes it necessary to examine the issue. In this direction, first of all, the concept of gig economy is explained in the study, the discussions about the concept and the transformation it creates in employment relations are included. Secondly, the gig economy is evaluated together with precarious employment. Then, Uber, which is taken part in the gig economy and provides services in the field of personal passenger transportation, is examined. In this context, the positive and negative aspects of Uber in working life are tried to be revealed, employment relations, legal struggles of Uber drivers for the classification problem, unionization attempts and strike pratices are examined in detail

Keywords: Gig economy, Uber, insecurity, precarious employment, algorithm, technology

\section{Giriş}

Teknolojik ilerlemeler, sanayi devriminden günümüze uzanan süreçte, üretim faktörlerini değiştiren, emek sürecini dönüştüren ve toplumsal yap 1 içindeki tüketici davranışlarını farklılaştıran en önemli etkenlerin başında gelmektedir. Teknolojinin iş ilişkilerini dönüştürme, değiştirme ve etkileme süreci yeni değil, aksine, tarihsel kökleri olan bir süreçtir. Teknoloji alanındaki gelişmeler, ekonomik, sosyal, siyasal ve toplumsal alanlardaki değişikliklerin bir sonucu olarak ortaya çıkmakta ve daha önce var olan birikim temelleri üzerine gelişim göstermektedir. Bu bağlamda, zaman içerisinde meydana gelen teknolojik dönüşümleri, işgücü ve diğer üretim faktörleri açısından incelemek büyük önem taşımaktadır.

$\mathrm{Bu}$ doğrultuda, yirmi birinci yüzyll, teknolojik araçlara sahip olmanın veya kullanma oranlarının her geçen zaman dilimi içinde artış gösterdiği, tüketici davranışlarının farklılaşı̆̆̆, mevcut istihdam modellerinin dönüştüğü veya ortadan kalktığı ve yeni istihdam modellerinin ortaya çıktı̆̆ bir yüzyıl olarak ifade edilmektedir. Bu bağlamda, küresel ölçekte internete erişim sağlayan kişi sayıs 1996 yllında 20 milyon 
kişi olarak tahmin edilirken, bu sayının 2021 yllında 5 milyar kişiyi aşmış olduğu tahmin edilmektedir. Özellikle, internet kullanıcı sayısının ve bilgi ve iletişim teknolojilerindeki ilerlemelerin hızlanmas1, en yoğun şekilde üretim sürecini ve işyeri ölçeğini etkilemektedir. $\mathrm{Bu}$ gelişmelerle birlikte, akıllı cep telefonu, bilgisayar ve internet aracılı̆̆yla gerçekleştirilen iş modellerinin yaygınlık kazandığı da bilinen bir gerçektir.

Gig ekonomisi, işgücü piyasası politikaları aracıllğıyla ulus devletlerin çalışanları koruyucu düzenlemelerinin zayıflatıldığı, bilgi ve iletişim teknolojilerindeki ilerlemelerin hızlandığı, çalışma yaşamındaki ekonomik ve sosyal risklerin tek tarafa (işçilere) indirgeyen istihdam modellerinin yaygınlık kazandığı, emeği yeniden metalaştırıcı eğilimlerin artış gösterdiği ve küresel işgücü piyasasında işsizliğin ve düşük gelirin kalıcı duruma geldiği, çok boyutlu ve kapsamlı bir sürecin sonunda ortaya çıkan, yeni bir iş organizasyonu modelini ve ekonomik olguyu ifade etmektedir. Bu kapsamda, çalışmanın ilk kısmında, gig ekonomisinin kavramsal çerçevesi çizilmeye çalışılmış, kavrama yönelik yapılan tartışmalara yer verilmiş ve iş ilişkilerinde ortaya çıkardığ1 dönüşüm irdelenmiştir. Çalışmanın ikinci kısmında, gig ekonomisinin uzun yıllardır tartısılan güvencesiz istihdam ile birlikte değerlendirilmesi yapılmış, benzer ve ayrık yönleri değerlendirilmiştir. Çalışmanın son kısmında gig ekonomisi içinde en yaygın olarak bilinen Uber incelenmiştir. Uber'in iş ilişkileri açısından yarattığı olumlu ve olumsuz yönler değerlendirilmiş, Uber sürücülerinin iş hukukundan doğan sinıflandırma sorununa yönelik hukuksal mücadeleleri, sendikalaşma girişimleri, farklı ülkelerde ve farklı zamanlarda ortaya çıkan grev uygulamaları detaylı bir biçimde ele alınmıştır.

\section{Gig Ekonomisinin Kavramsal Çerçevesi}

Gig ekonomisi kavramı, bir bireyin kısa süreli işler bulmak ve yerine getirmek için, bir firma/aracı, tarafindan sağlanan bir uygulamaya veya internet sitesine erişim sağlayarak, ardından işi gerçekleştirdiği ve genellikle üç tarafin yer aldığı iş organizasyonunu açıklamak için kullanılmaktadır (Kallaberg ve Dunn, 2016: 11; Donovan vd., 2016: 1-2; De-Stefano, 2016: 475; Aloisi, 2016: 654-655; TodoliSignes, 2017: 194-195; De-Stefano, 2018: 69; Johnston ve Land-Kazlauskas, 2019: 3; Chen, 2020: 126; Erdut, 2021: 41). Birey, uygulamaya veya internet sitesine akıllı cep telefonu, tablet veya bilgisayar aracıllğıyla erişim sağlamakta ve ardından işi gerçekleştirmektedir (Dunn, 2018: 6-7; Woodcock ve Graham, 20201: 18; Webster, 2016: 2). Kişi gerçekleştirdiği her iş sonucu ücret kazanc1 elde etmektedir (Aloisi, 2016: 653; De-Stefano, 2018: 69; Johnston ve Land-Kazlauskas, 2019: 3). Son olarak, uygulama veya internet sitesi, ücret kazancinın bir kısmını "komisyon ücreti2" adı altında keserek iş sürecini sona erdirmektedir (Donovan vd., 2016: 1-2).

${ }^{1}$ Not: Jamie Woodcook ve Mark Graham tarafından yazılan "Gig Ekonomisi: Kritik Bir Giriş" kitabının sayfa numaraları "E-Kitap” formatına göre verilmiştir.

2 Gig ekonomisi firmalarının değişen oranlarda ücret kesintisi yaptığı bilinmektedir. Örneğin, Uber, sürücülerden yüzde 25 (Uber, 2021); AirBnb ev sahiplerinden yüzde 3, 
Gig ekonomisi platformlarının düşük giriş engelleri, platformların hızlı büyümesini sağlamakta ve yerel ve/veya küresel işgücü arzını arttırmaktadır (Woodcock ve Graham, 2020: 16). Webster, gig ekonomisi platformlarına katullm için en az üç ön koşulun bulunduğunu belirtmektedir. Bunlardan ilki, dijital bir cihaza (bilgisayar, tablet veya akıllı cep telefonu) veya araca (araba, motor, bisiklet), sahip olma gereksinimidir. İkinci olarak, kişi tarafindan internete erişiminin (ev, kafe, üniversite) sağlanması gerekmektedir. Son olarak ise platformların iş özelliğine göre talep edilen becerilere (çeşitli bilgisayar becerileri, araba ehliyeti/motor veya bisiklet sürme) sahip olunması istenmektedir (Webster, 2016: 2). Bu bağlamda, gig ekonomisi platformlarına katllım için internet ve akıllı cep telefonu sahipliği büyük önem taşımaktadır.

Gig ekonomisine yönelik literatür incelemesi yapıldığında kavramın kullanımına ilişkin üzerinde mutabık kalınan bir tanıma rastlanmamaktadır. Zira gig ekonomisi kavramı yerine, talep yönlü ekonomi; işbirlikçi ekonomi; spesifik çevrimdışı mikro çalışma; 1099 ekonomisi; paylaşım ekonomisi; platform ekonomisi; freelance ekonomisi; Uber ekonomisi, gibi pek çok farklı kavramın tercih edildiği ve literatürde kullanıldığ bilinmektedir (Kallaberg ve Dunn, 2016: 10; Donovan vd., 2016: 1, Aloisi, 2016: 654; Risak, 2017: 3; Todoli-Signes, 2017 : 194; Fishman, 2019: 356; Chen, 2020: 125; Erdut, 2021: 30).

Gig ekonomisine ilişkin birbirinden farklı kavramsallaştırmanın daha çok politik ve sosyal yönlerinin gizlenmesine yönelik yapıldığını ileri sürenler görüşler bulunmaktadır (Khreiche, 2018: 21; Muntaner, 2018: 598-599). Woodcock ve Graham, kavram tartışmasına yönelik Arun Sundararajan tarafindan kullanılan "paylaşım ekonomisi" ifadesinin oldukça iyimser olduğunu belirtmektedirler (Woodcock ve Graham, 2020: 26). Kavramsallaştırmaya yönelik yürütülen tartş̧malardan birkaç örnek verilecek olursa; Schor, bu karmaşıklığı şu sözler ile açıklamaktadır:

"Bu [karmaşık durumu] birkaç yenilikçiye [kişiye] sorduğumda, analitik olmaktan ziyade pragmatiklerdi: platformlar ve basin tarafindan yapilan bu öz tanımlama, kimlerin işin içinde kalıp, kimlerin işin dışında bırakılacağını belirliyor” (2014: 2).

Eurofound tarafindan yayımlanan "Dijital Çağ: Seçilen Platform Çalışması Türlerinin İstihdam ve Çalışma Koşulları" adlı raporunda ise, kavramsallaştırmaya yönelik aşağıdaki ifade dikkat çekmektedir:

[Avrupa Parlamentosu] İç Politikalar Genel Müdürlügü̆, "paylaşım ekonomisi", "işbirliğine dayalı ekonomi" ve "gig ekonomisi" gibi terimleriyle ilgili olumlu ve olumsuz çağrışımlara dikkat çekerek, Avrupa Parlamentosu'nun İstihdam ve Sosyal İşler Komitesine, bu faaliyetleri tartşsmak için en tarafsız terim olarak "platform

konaklayanlardan ise yüzde 14,2 (Airbnb, 2021); Amazon Mechinal Turks çalışanlardan minimum yüzde 20 (MTurk, 2021) ve TakeLesson ise ders miktarına göre yüzde 10 ila yüzde 40 arasında değişen ücret kesintisi yapmaktadırlar (TakeLesson, 2021). 
ekonomisi" ve "platform çalışması" terimlerini kullanma konusunda öneride bulunmuştur (2018: 2).

Kavram karmaşasının esas nedeni, "uygulama ve/veya bir internet sitesi" aracıllğıyla gerçekleştirilen işlerin kısa bir geçmişinin olması -kimi yazarlar 2008 ekonomik krizi sonrasını işaret etmektedir- (Aloisi, 2016: 671; Vallas ve Schor, 2020: 274) ve taraflar arasındaki güç ilişkilerin belirgin olmamasından kaynaklanmaktadır (Khreiche, 2018: 21-22). Bir başka ifadeyle; yukarıda sıralanan kavramların emek-sermaye çatışmasında taraflar arasındaki güç ilişkilerinin gizlenmesinde önemli rol oynadığını, bireyler tarafindan teknolojinin nasıl algılandığ1 ve isimlendirilmesine yönelik girişimlerin etkili olduğu ifade edilmektedir (Stanford, 2017: 383; Khreiche, 2018: 23-24).

Gig ekonomisine yönelik literatür incelemesine devam edildiğinde, üzerinde anlaşma sağlanamayan bir diğer konunun ise taraflar arasında kurulan iş ilişkisinin niteliğidir. Gig ekonomisinde genellikle ortaya çıkan üç taraflı iş ilişkisine yönelik çok farklı tanımlamalar yapıldığı bilinmektedir. Örneğin, Harris ve Krueger (2015: 11) "bağımsız işçiler, müşteriler ve aracılar" şeklinde tanımlamakta, Lehdonvirta vd. (2019: 590) "üçlü bir sağlayıc1-platform-müşteri”" olarak ifade etmekte, Avrupa Komisyonu (2016: 4) "hizmet sağlayıcılar, kullanıcılar ve aracılar" olarak siniflandirma yapmakta ve Avrupa Parlamentosu (2017: 10) ise Avrupa Komisyonundan farklı olarak, "platform çalışanı, çevrimiçi platform ve müşteri" olarak değerlendirmektedir.

Şekil 1: Gig Ekonomisinin Sınıflandırılmas1

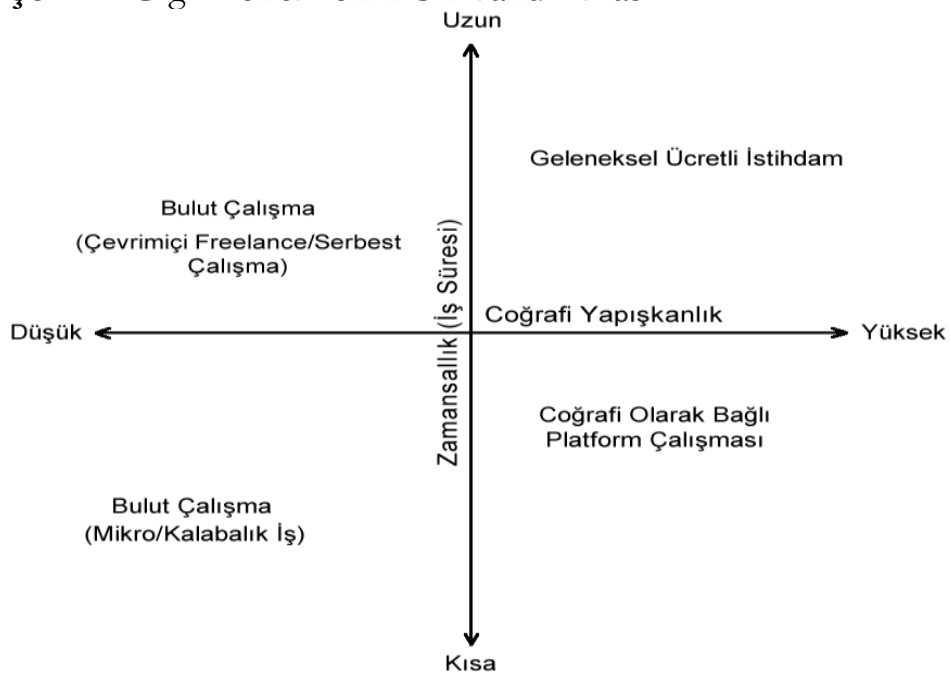

Kaynak: (Woodcock ve Graham, 2020: 72) ${ }^{3}$

3 Coğrafi yapışkanlık (geographic stickiness) veya coğrafi örtüşme, arz ile talebin aynı coğrafi bölgede bulunma zorunluluğunu açıklamaktadır. Örneğin, talep üzerine gig 
Gig ekonomisi platformlan, hem işin niteliğinden dolay1, hem de işin gerçekleştirildiği mekân kısıtlaması nedeniyle kendi içinde talep yönlü ve çevrimiçi çalışma şeklinde genellikle iki alt başlık altında sınıflandırılmaktadır (De Stefano, 2016: 471; Stewart ve Stanford, 2017: 421-422; Wood vd., 2019a: 932; Wood vd., 2019b: 57).

\section{Talep Yönlü Çalışma}

Bu çalışma modelinde, arz ile talebin coğrafi olarak birbirine yakın olduğu, akıllı cep telefonu uygulamaları aracillğılla talep edilen hizmetin platforma, platformun ise arza yönlendirdiği, uygulama aracilığılla arz ile talebin eşleştirildiği ve ardından işin/hizmetin gerçekleştirildiği bir çalışma biçimi ortaya çıkmaktadır (Stewart ve Stanford, 2017: 424-425). Talep üzerine platformlar/çalışma, yerel düzeyde gerçekleştirildiğinden, daha ziyade, gıda dağıtım, yolcu taşıma hizmetleri, yaşlı bakımı, sağlık hizmetleri (hemşire), avukatlık, mimarlık, temizlik gibi pek çok farklı hizmet türleri burada yer almaktadır (Friedman, 2014: 172; Woodcock ve Graham, 2020: 11).

\section{Çevrimiçi Çalışma}

$\mathrm{Bu}$ çalışma modeli, yer-zaman kısıtlaması olmadan internet üzerinden internet siteleri aracıllŏ̆yla gerçekleştirilen işleri kapsamaktadır (De-Stefano, 2016: 474; Aloisi, 2016: 661; Wood vd., 2020: 74-75). Çevrimiçi platformlar genellikle bilgi ve iletişim teknolojisiyle ilgili işleri kapsamakta ve yaklaşık kırk farklı hizmeti içerisinde barındırmaktadır (Kassi ve Lehdonvirta 2018: 244; Wood vd., 2019a: 933).

Pek çok yazar, gig ekonomisinin, küresel işgücü piyasasının küçük bir kısmina karşllk geldiğini ifade etmektedir (Stewart ve Stanford, 2017: 423; Kässi ve Lehdonvirta, 2018: 242; Johnston ve Land-Kazlauskas, 2019: 3). Ancak gig ekonomisi platformları hem yerel düzeyde, hem de uluslararası ölçekte gerçekleştirilen hizmetlerin her geçen gün farklılaşmakta olduğu, platformların hızla büyüdüğü ve iş ilişkilerini bozan bir şekilde ilerlediği bilinen bir gerçektir (Erdut, 2021: 33). Çevrimiçi ve talep yönlü çalışma platformlarının sayısı 2010 'da 142' iken 2020'de 777'nin üzerine çıktığı ileri sürülmektedir (ILO, 2021: 19). Bu nedenle, gig ekonomisi platformları aracilığıla tek gelir kaynağına sahip olmak veya ek gelir kazancı elde etmek amacıyla çalışan işçi sayısının tespit edilmesi oldukça zordur (De-Stefano, 2016b: 466; Woodcock ve Graham, 2020: 64). Bu durumun en az üç nedeni bulunmaktadir.

Öncelikli olarak, gig ekonomisi platformlarında yer alan işçilerin işgücü devrinin yüksek olduğu bilinmekte (terk $/ \mathrm{kat}$ llım) (Johnston ve Land-Kazlauskas, 2019: 4) ve platformlardan çıkış yapan mevcut işgücünün belirli zaman aralığı sonras1 tekrardan internet sitelerinde/uygulamalarda aktif oldukları bilinmektedir. İkinci olarak, gig ekonomisi içinde yerel düzeyde faaliyet yürüten şirketlerin yeni

ekonomisi platformlarında arz ile talep birbirine mekânsal olarak bağlllık (Uber sürücüsüyolcu) yüksek düzeyde olurken, çevrimiçi gig ekonomisi platformlarında (yazılımc1- birey veya şirket) ise mekânsal bağlılık azalmaktadır. 
merkezlere genişlemesi (Uber), benzer (Lyft) veya farklı işkollarının faaliyete başlaması (Foodora) ve yerel çevrimiçi platformların kurulması veya farklılaşması ve bu platformların zaman içinde genişlemesi işçi sayısının tespitini oldukça zorlaştırmaktadır ${ }^{4}$. Son olarak ise, hem yerel düzeyde, hem de çevrimiçi platformlarda çalışma imkânının olmasıdır. Örneğin, kişi, gündüz saatlerinde Uber veya Deliveroo için hizmet sağlayabilir, günün geri kalan sürelerinde ise Upwork veya Amazon Mechinal Turk için talep ettiği işi tamamlayabilir. Bununla birlikte kişinin birden fazla çevrimiçi gig ekonomisi platformlarına üye olması da mümkündür. Anwar ve Graham (2020: 1279), bu durumu, Afrika kitasinda gerçekleştirdikleri araştırmada gözlemlemiştir. Çevrimiçi gig platformu çalışanları, aile bireylerinin adlarını kullanarak birden fazla hesap oluşturup iş tekliflerini arttırmakta, böylece bağlantı sayısını fazlalaştırma olanağına da ulaşmaktadırlar. $\mathrm{Bu}$ olasıllı̆ın yanında aynı işkolunda birden fazla platform için çalışmak da mümkündür. Çevrimiçi gig ekonomisi platformları içerisinde en yüksek kullanıcı içeren Upwork ve Freelancer internet siteleri için aynı anda çalışma imkânı bulunmaktadır. Bu durumun yerel düzeyde (ABD'de) yansıması ise işçilerin hem Uber için, hem de Lyft için çalışması mümkün olmaktadır (Schmidt, 2017: 20; Cornelissen ve Cholakova, 2019: 6; HyreCar, 2021). Bu olas1liklar hesaplaninca gig ekonomisi platformlarında yer alan işçi sayısının hesaplanması da her geçen gün daha da zorlaşmaktadır.

Yukarıda ifade edilen tüm olasılıklara rağmen, gig işçilerinin işgücü içindeki sayısal büyüklügünün tespiti konusunda, araştırmacılar, kamu kurumları, uluslararası kurum ve kuruluşlar, özel firmalar ve sivil toplum kuruşları tarafindan belirli zaman dilimini kapsayan ve ulusal ve/veya küresel işgücü büyüklügünü ölçmek için yapılan çeşitli çalışmalar bulunmaktadır (Gandini, 2019: 1041; Woodcock ve Graham, 2020: 65). Gig ekonomisinin büyüklüğünün tespiti için farklı zamanlarda ve farklı ülkelerde araştırmalar yapılmıştır. Örneğin, Katz ve Krueger tarafindan 2016 yılında yapılan araştırmada, ABD'de istihdamda yer alanların yüzde 0,5'inin gig platformlarda yer aldığ tespit edilmiştir (Schwellnus vd., 2019: 32). 2017 yllında gerçekleştirilen ve 7 Avrupa ülkesini kapsayan araştırmada ise toplam istihdamın yüzde 9 ila yüzde 22 arasında değişen oranda bir işgücü kitlesinin platformlarda yer aldığ1 tespit edilmiştir (Huws vd., 2017: 16). Farrell ve Greig tarafindan 2018 yilının Mart ayında ABD'de "JP Morgan" bankasının verileri kullanılarak yapılan araştırmada, hesap sahiplerinin (39 milyon) yüzde 1,1'inin platformlar aracilığıyla tam süreli veya kısmi süreli bir gelir elde ettiği tespit edilmiştir (Schwellnus vd., 2019: 32). Bir diğer araştırma ise, 2019 yılında Çin Halk

42009 yılında kişisel yolcu taşıma hizmeti amacıyla ABD'de kurulan Uber, 2021 y1lı itibariyle 70 'den fazla ülkede ve 900'den fazla şehir merkezinde faaliyet yürütmektedir. Sektörel rakibi Lyft ise 2012 y1lında kurulmuş olup ABD'de ve Kanada'da faaliyet yürütmektedir. Yemek teslimat platformları ise 2013 yllinda Deliveroo ve DoorDash, 2014 yilında UberEats ve Foodora ve 2015 yilında kurulan Glovo küresel ölçekte yaygınlaşan platformların başında gelmektedirler. 
Cumhuriyetinde gerçekleştirilmiş ve 75 milyon kişinin gig ekonomisi platformları aracılığıyla çalıştığını ortaya koymuştur (Wu vd., 2020: 2).

Diğer yandan, küresel işgücünün zaman içinde platformlar aracillğıyla daha yoğun şekilde istihdam edileceğini ileri süren görüşler bulunmaktadır. Bu görüşü destekler biçimde, Standing, 2025 yllinda küresel işgücünün üçte birinin platformlar aracıllğıyla gerçekleştirileceğini ileri sürmektedir (Standing'den aktaran Woodcock ve Graham, 2020: 12). Bir diğer tahmin ise McKinsey Enstitüsü tarafindan yapılmıştır. Enstitü, 2025 yılında işsiz veya kısmi süreli 200 milyon kişinin çevrimiçi platformlar aracilığıly ek gelir elde edeceğini tahmin etmektedir (Woodcock ve Graham, 2020: 12-13).

\section{Tanımı}

Gig kavramının kökeni üzerine uzlaşı sağlanamamış olduğu bilinmekte ve kavram üzerine tartışmalar güncel bir biçimde devam etmektedir (Dunn, 2018: 3). Gig kavramının kökenine yönelik üç farklı görüş bulunmaktadır. Bu görüşlerden ilki, Amerikan argo tarihi sözlüğüne göre "gig" kelimesinin "gag" kelimesinden türeyen bir kavram olduğudur (Wordspy, 2021). Argo sözlüğü, "gag” kelimesinin 1890 yılında kullanıldığını ve "cessitti eylem veya davranışlar; uygulama, is, yöntem vd. anlamlarına geldiğini ileri sürmektedir. İkinci olarak "gig" kavramının kökeni inceleyen araştırmacılar, kavramı parça başı çalışma ile ilişkilendirerek ilk kez 1908 yılında Green'in kitabında kullanıldığını belirtmişlerdir. Gig kavramının "ticari/iş ilişkisi, işlerin durumu ve girişim/olay anlamlarına geldiğini belirtmişlerdir. Son olarak, 1920'li yıllarda gig kavramın tanımı genişletilerek müzisyenlerine yönelik "tek seferlik" performans anlamı kazandırlmıştır (Dunn, 2018: 3).

Gig kavramı, ABD'de kafe/bar gibi mekân çalışanlarına ve özellikle de caz sanatçlarına yönelik geliştirilmiştir. Özellikle, gig işçileri mekân tarafından veya başka aracıların (mekânı kiralayan tarafindan; doğum günü/parti) talebi üzerine gündelik, geçici veya belirli süreli istihdam edilen sanatçılara yönelik olarak kullanılmıştır. $\mathrm{Bu}$ anlamda, talep üzerine istihdam edilen müzisyenlerin kafe veya barlarda sergilemiş oldukları performansları neticesinde istihdam edilmelerine veya edilmemelerine karar verilmektedir (Friedman, 2014: 172; Muntaner, 2018: 598; Woodcock ve Graham, 2020: 11). Gig kavramı yukarıda açıklandığı üzere son on yıla kadar ABD'de müzisyenlere yönelik geliştirilmiş bir kavramı açıklamaktaydı. ABD'de müzisyenlerin çalışma koşullarında sıklıkla karşılaşılan geçici olma özelliği veya atipik olarak nitelendirilecek yap1, 2008 küresel ekonomik krizi sonrasında çalışma yaşamında ileri teknolojinin devreye sokulmasıyla iş ilişkisini yeniden biçimlendirilen ve gig ekonomisi olarak nitelendirilen bir yapıyı gündeme getirmiştir.

Gig kavramı ile gig ekonomisi işçilerinin karşılaş̧ı̆̆ güvencesizlik, istikrarsızlık, sosyal korumadan yoksunluk konularında ve diğer (parça başı ücret, fazla çalışma 
ve fesih) konularda benzerlikler gösterse de birbirlerinden yapısal olarak farklı özellikler taşıdığını belirtmekte yarar bulunmaktadır. Bu doğrultuda, gig ekonomisi platformları teknolojik gelişmelerin etkisi ile zaman içerisinde çeşitlilik göstermekte ve bu çeşitliğin meydana getirdiği sorunlarla farklılaşmaktadır. Gig ekonomisi içinde, yolcu taşıma hizmetleri, yaşlı bakımı, temizlik, muhasebe, avukatlık, mimarlık, köpek gezdirme, akademik yazarlık, müşteri hizmetleri ve bilgi ve iletişim teknolojisi aracıllğıyla yapılan pek çok işkolunun gig ekonomisi içerisinde yer aldığ1 ve işkollarının sürekli genişlemekte olduğu bilinmektedir (Friedman, 2014: 172; Lobel, 2017: 1-2; Woodcock ve Graham, 2020: 11).

Gig ekonomisi, teknolojik gelişmelerin bir sonucu olarak işgücü piyasası içerisinde işverenler tarafindan yeni ve esnek bir istihdam modeli olarak kullanılmas1 (Schwellnus vd., 2019: 5; Johnston ve Land-Kazlauskas, 2019: 1), geleneksel işlerin teknoloji ile yeni bir form kazanması (Lobel, 2017: 1-2), ulusal kalkınma (Wood vd., 2019b: 57), yeni bir istihdam alan1 (Aloisi, 2016: 653; Kassi ve Lehdonvirta, 2018: 241), çalışanlar için ek gelir firsatı veya boş zaman/iş-yaşam dengesi gibi konulardaki esneklik taleplerine uyumu (De Stefano, 2016a: 479) ve sermaye için yeni bir artık değer üretimi ve sermaye birikimi modelini oluşturması açısından dikkat çekicidir (Tassinari ve Maccarrone, 2020: 37-38). Gig ekonomisi yukarıda sıralanan tüm aşamaların bir arada varlık gösterdiği yeni bir süreci ifade etmektedir.

Gig ekonomisi, işgücü piyasasında esnek istihdam modellerini derinleştiren (Aloisi, 2016: 655; Erdut, 2021: 45), platformların puanlandırma, derecelendirme ve sinıflandırma uygulamalarıla emek üzerindeki denetimi arttıran (Todoli-Signes, 2017: 198; Gandini, 2019: 1049-50) ve çalışma yaşamında meydana gelebilecek sosyo-ekonomik riskleri işçiler aleyhine tek tarafa indirgeyen iş organizasyonunu ifade etmektedir (Friedman, 2014: 172; De Stefano, 2016a: 480-81; Wood vd., 2019b: 59). Gig ekonomisi, teknolojik gelişmelerin işgücü piyasası içerisinde yeni bir aşaması olduğu gibi son aşaması olması da beklenmemektedir. 
Şekil 2: Gig Ekonomisinde Üç Taraflı İş İlişkisi

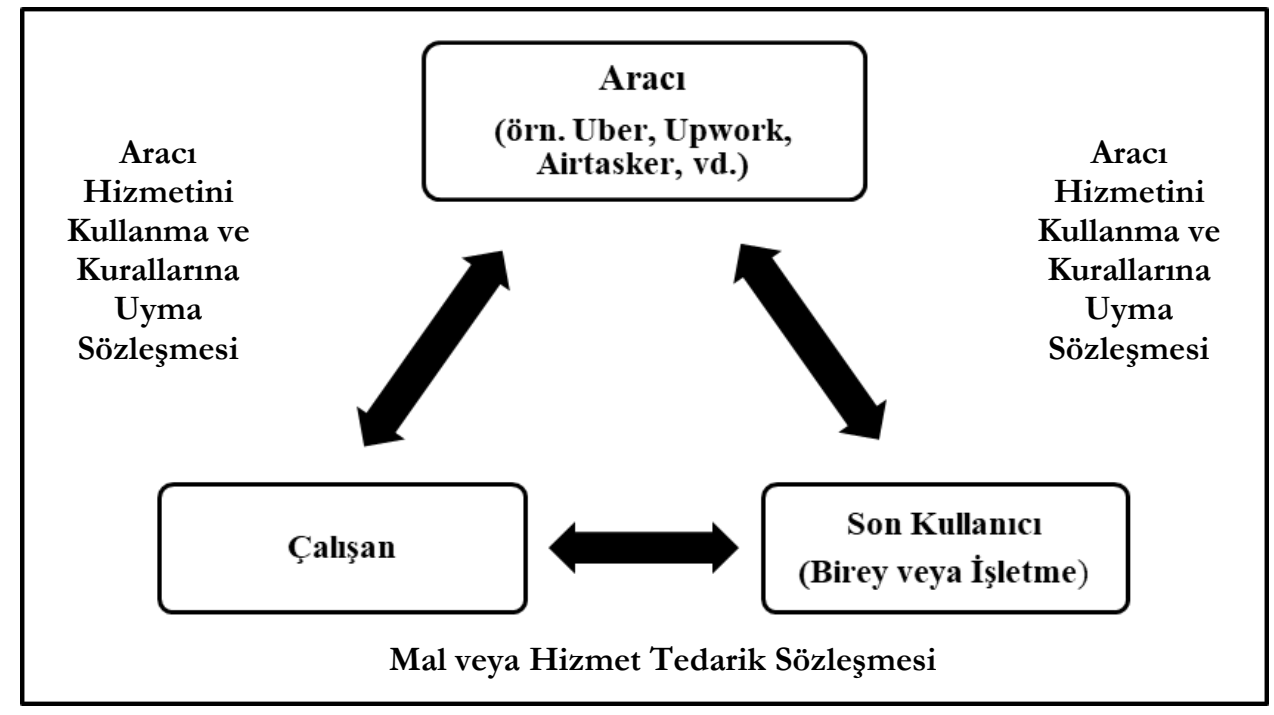

Kaynak: Stewart ve Stanford, 2017: 425

Gig ekonomisi, üç taraflı iş modeli üzerine varlık gösteren ve çalışma yaşamına etki eden eski bir sürecin, teknoloji ile yeniden şekillendirilen yeni bir süreci de anlatmaktadır (Kallaberg ve Dunn, 2016: 11; Stewart ve Stanford, 2017: 424-25; Schmidt, 2017: 10). Gig ekonomisi içerisinde, platform, işçi ve birey veya işletme arasında kurulan üç taraflı iş ilişkisi, taraflar arasında gerçekleşecek işlere yönelik önceden hazırlanmış ve kabul edilmiş hizmet sözleşmesi ile yürütülmektedir (Kallaberg ve Dunn, 2016: 11; De Stefano, 2016: 475; TodoliSignes, 2017: 194-95). Gig ekonomisinin üç taraflı iş ilişkisi, platformlar, görevi gerçekleştirilecek işçi ve hizmete sahip olacak (son alıcılar) birey veya işletmeler arasında, akıllı cep telefonu uygulamaları veya çevrimiçi platformlar (internet) aracıllı̆̆yla gerçekleşen istihdam modelini ifade etmektedir (Donovan vd., 2016: 1; De Stefano, 2016a: 473-74; De Stefano, 2016b: 463; Stewart ve Stanford, 2017: 421; Muntaner, 2018: 598).

Gig ekonomisi genellikle üç taraflı iş ilişkisi üzerine inşa edilmekle beraber bazı sektörlerde bu iş ilişkisinin dört taraflı iş ilişkisini kapsadığı da görülebilmektedir. Dört taraflı iş ilişkisi genellikle gıda dağıtım hizmetlerinde ortaya çıkmakta ve platform (Deliveroo, Foodora), restaurant, müşteri ve kurye arasında kurulan bir iş iliş̧isi biçiminde şekillenmektedir (Heiland, 2021: 2). Bu anlamda, gig ekonomisindeki iş ilişkisinin genellikle üç tarafll ${ }^{5}$ olduğu bilindiğinden

5 1970'li y1llardan itibaren standart istihdam ilişkisinin çözülmesi yeni istihdam modellerinin ortaya çıkmasını hızlandırmıştır. Özellikle, 1980 sonrası yaygınlaşan geçici iş ilişkisi adı 
çalışmanın bundan sonraki bölümlerinde salt üç taraflı iş ilişkisi üzerinde durulacaktır.

Gig ekonomisi ile birlikte ortaya yeni bir formu çıkan üç taraflı iş ilişkisinin, taraflar üzerinde eşit/benzer sonuçlar doğurmadığı bilinen bir gerçektir. Nitekim ortaya çkan iş ilişkisi platformlara; gözetim ve kontrol gücü (Gandini, 2019: 104950), sermaye birikimi (Johnston ve Land-Kazlauskas, 2019: 1) ve iş hukuku düzenlemelerinden kaçış (Lobel, 2016: 2; Todoli-Signes, 2017: 194) gibi firsatlar sağlamaktadır. Bu durum işçiler için sosyal ve ekonomik korumalardan yoksunluk, belirsizlik ve güvencesizlik durumlarını derinleştirmekte ve kalıcı hale gelmesine yol açmaktadır (Friedman, 2014: 172; Aloisi, 2016: 653; Lobel, 2016: 2). Son kullanıcılar (birey veya işletme) ise, platformların faaliyet gösterdiği ulusal veya uluslararası işgücü piyasalarında emek üzerinden gerçekleştirilen birikimden ve piyasadaki diğer firmalarla aralarındaki rekabetten yararlanmaktadır. Böylece düşük işlem maliyetine ve yüksek pazarlık gücüne erişim sağlayan ve firsatlardan faydalanan üçüncü tarafı temsil etmektedir (Aloisi, 2016: ; 670; Kalleberg ve Dunn, 2016: 12; Todoli-Signes, 2017: 194-5; Graham ve Amir Anwar, 2018: 4).

Gig ekonomisi içinde faaliyet gösteren platformlar kendilerini işveren olarak değil arz ile talebi buluşturan "aracı bir yapı" olarak nitelendirmektedir (Lobel, 2016: 6; De Stefano, 2016a: 467-68; Erdut, 2021: 47). Gig ekonomisi firmalar1 ile işçi arasında kurulan iş ilişkisinin "aracı bir yapı-bağımsız yüklenici" üzerinden gerçekleştirilmesi pek çok sorunun ortaya çıkmasına neden olmaktadır. Özellikle gig işçilerin sınıflandırma olarak işçi değil, "bağımsız yüklenici" olarak sınıflandırılması iş hukuku, sosyal güvenlik hukuku ve borçlar hukukunun işçilere sağlamış olduğu koruyucu düzenlemelerinin dışında kalmasına yol açmaktadır (Donovan vd., 2016: 8; Aloisi, 2016: 673). Bu siniflandırma sonucu, platformlar içerisinde yer alan işçiler, başta asgari ücret hakkı, işsizlik ödeneği hakkı, sosyal güvenlik hakk1, fazla çalışma ücreti hakk1, kıdem ve ihbar tazminatı hakk1 ve sendikalaşma hakkından yoksun kalmalarına neden olmaktadır (Stefano, 2016: 478479; Johnston ve Land-Kazlauskas, 2019: 3). Platformların arac1 bir yap1 olarak yanlış sınıflandırıldığına dair işçiler, işçi dernekleri ve çeşitli kuruluşlar tarafindan açılan pek çok dava bulunmaktadır (Donovan vd., 2016: 8-9; Aloisi, 2016; Johnston ve Land-Kazlauskas, 2019: 5).

altında kurulan üç taraflı iş ilişkisi bu dönüşümün en yaygın örneğidir. Geçici iş ilişkisinde ve gig ekonomisinde meydana gelen üç taraflı iş ilişkisi ise birbirinden yapisal olarak farklıdır. Geçici iş ilişkisi, belirli iş kollarında ve belirlenen sürelerde kurulan üç taraflı hukuki ilişkiyi ifade etmekte olup, iş sözleşmesinden veya alt işverenin taraf olduğu toplu is söそleşmesinden doğan tüm hukuki güvenceyi sağlamakla yükümlü tutulduğu bir iş ilişkisidir. Gig ekonomisinde kurulan üç taraflı iş ilişkisi (platform-işçi-müşteri) ise hem müşteriplatform, hem de platform-işçi arasında kurulan sözleşme ile şekillenmektedir. Gig ekonomisi platformlarının oluşturduğu algoritmalar ile işgücünü kontrol eden ve derecelendirme sistemleri ile iş ilişkisinin sürekliliğini ortadan kaldıran bir yapıyı inşa ettiği de bilinmektedir. 
Gig ekonomisi platformlarında yer alan işçilerin ve/veya temsilcilerinin, hizmet gerçekleştirdikleri platformların "aracı kurum" niteliğinden daha çok "işveren" olduklarını yönelik düzenlemelerin gerçekleştirilmesi yönünde talepleri bulunmaktadır. Yasal düzenlemeler veya yarg1 tarafindan, platformların yeniden sınıflandırılması ve işveren olarak tespit edilmesinin çalışanlar açısından iş hukukundan doğan koruyucu düzenlemelere kavuşmaları anlamına geleceği de bilinmektedir. (Aloisi, 2016: 677).

Nitekim, 2016 yllında İngiltere'de taşımacılık hizmeti gerçekleştiren Uber'e yönelik açılan tespit davası sonucu Uber sürücülerinin "bağımsız yüklenici" sınıflandırması yerine işçi olarak sınıflandırılması gerektiğine karar verilmiştir. Böylelikle, Uber çalışanlarına iş hukukundan doğan, asgari ücret, hafta tatili ücreti ve diğer haklardan yararlanma olanağ1 doğmuştur (Stewart ve Stanford, 2017: 424). Ancak Uber tarafindan dava yüksek mahkemeye taşınmış ve 2021 yllında İngiltere Yüksek Mahkemesi sürücülerinin bağımsız yüklenici değil işçi olarak nitelendirilmesi gerektiğine (karar aşağıda detaylıca incelenecektir) karar kılınmıştır. Platformların, kendilerini işveren olarak değil arac1 bir yap1 olarak nitelendirmelerinin temel nedeni, hizmetin gerçekleştirilmesi için gerekli üretim araçlarını temin etmemek ve/veya bu yeni çalışma ilişkisiyle mevcut hukuki korumalardan kaçınarak esasen yeni bir sermaye birikim modelini inşa etmek istemeleridir (Stewart ve Stanford, 2017: 421).

\section{Gig Ekonomisi ve Güvencesizlik}

İkinci Dünya Savaşı sonrası, gelişmiş kapitalist ülkelerde egemen hale gelen fordist üretim, keynesyen devlet müdahaleleri, refah devleti uygulamaları, sendikalaşma ve toplu sözleşme haklarının yaygınlaşması ve emek ile sermaye tarafları arasındaki uzlaşının sağlanması (Jessop, 2005: 313; Arın, 2013: 47; Harvey, 2015: 18) gibi gelişmelerin iş ilişkilerine yönelik en önemli kazanımlarının başında güvenceli istihdamı yaygınlaştırmış olması gelmektedir (Cranford vd., 2003: 7; Benach vd., 2014: 231; Harvey, 2019: 156-157). Güvenceli istihdam, işçilerin tek bir işverene bağlı olarak, işverenin sahip olduğu işyerlerinde çalışan, işverenin veya vekilinin kontrolü altında denetlenen, sosyal haklar ile desteklenen, sendikalaşma ve toplu sözleşme hakkı tanınan ve tam süreli ve sürekli istihdamın benimsenmiş olduğu bir modeli temsil etmektedir (Cranford vd., 2003: 7; Temiz, 2004: 55-56). Gelişmiş kapitalist ülkelerde benimsenen fordist üretim yapısının, güvenceli istihdam modelinin, uygulanan ekonomi ve sosyal politikaların 1970'li yılların ortalarına kadar devam ettiği bilinmektedir (Rodgers, 1989: 1; Kallaberg, 2009: 2).

1970'li yıllar, kâr hadlerinin düşüşe geçtiği, büyüme oranlarının azaldığı, işsizlik oranlarının yükseldiği (Harvey, 2019: 172), üretim ve verimlilik krizinin ivme kazandığ1 (Arın, 2013: 49-58), teknolojik gelişmelerin işgücü içerisinde daha yoğun biçimde kullanılmaya başlandığ1 ve tüm bu gelişmelerin sonucunda sermayenin birikim krizine girdiği bir süreci anlatmaktadır (Öngen, 2004: 249). 
$\mathrm{Bu}$ dönemde, sermayenin içine girmiş olduğu birikim krizinin sona erdirilmesine yönelik, ulus devletler, uluslararası kuruluşlar ve sermaye grupları tarafından çeşitli politika önerileri geliştirilmiştir. Öncelikli olarak, uluslararası rekabete uyumun sağlanmasına ve ivme kazanan isssizlik oranlarının azaltılmasına yönelik yeni liberal politika başlıkları altında öneriler hazırlanmıştır. Bu dönemde, Uluslararası Para Fonu ve Dünya Bankası'nın ulus devletlere önerdiği, yeni liberal çözüm önerileri arasında, kamu iktisadi teşebbüslerinin özelleştirilmesi, işgücü piyasalarının esnek bir yapıya dönüştürülmesi ve devletin ekonomik ve sosyal alandan geri çekilmesi görüşleri ön plana çıkmıştır (Zabc1, 2002: 162; Erdut, 2007 : 12-13; Koray: 2018: 202).

$\mathrm{Bu}$ doğrultuda, öncelikle fordist üretim modelinin kademeli olarak sonlandırilması planlanmış ve işgücü piyasalarında esnek istihdam modelleri yaygınlaştırılmıştır. İkinci olarak, güvenceli istihdamın sona erdirilmesine yönelik politikalar güç kazanmıştır. Ancak bu iki uygulamayla yetinilmeyip uzun yıllar boyunca sınıf mücadeleleri sonucu kazanılmış sosyal hakların kesintiye uğratılması veya kademeli olarak terk edilmesi hedeflenmiştir (Öngen, 2004: 248-9; Benach, vd., 2014: 231-2). Bu bağlamda, gelişmiş ve gelişmekte olan ülkelere dayatılan yeni çözüm önerileri sonucunda, emek aleyhine olacak şekilde yeni düzenlemeler gerçekleştirilmiştir. $\mathrm{Bu}$ anlamda, işçilerin sendikal yoğunluklarını azaltacak ve sendikal güçlerini etkisizleştirecek ekonomik, sosyal, siyasal ve hukuksal düzenlemeler belirtilen dönemde hayata geçirilmiştir (Erdut, 2004: 31-32).

Küresel ölçekte yaygınlık kazanan güvencesiz istihdamın tanımlanmasına yönelik girişimlere ise ilk kez 1970'li yıllarda başlandiğı bilinmektedir (Hacısalihoğlu, 2014: 12-15). Güvencesizlik, çok boyutlu ve kapsamlı bir süreci ifade etmektedir. Güvencesizlik, iş, istihdam, gelir, temsil ve sosyal koruma güvencesizliği şeklinde beş ${ }^{6}$ temel kategoride değerlendirilmektedir (Cranford vd.,

6 Güvencesizlik aşamaları sırasıyla şu şekilde sınıflandırılmaktadır. İlk olarak, iş güvencesizliği, kısa süreli iş sözleşmeleri ile istihdam edilme veya iş sözleşmesinin sona erdirilmesine yönelik hukuksal güvencelerin zayıf olması nedeniyle işsiz kalma riskinin yüksek olması olarak açıklanmaktadır. İstihdam güvencesizliği ise işgücü piyasalarında esnek istihdam modellerinin yaygınlık kazanması sonucu çalışanların istihdam modelleri üzerinde söz sahibi olmasını veya korumasını azaltmaktadır. Gelir güvencesizliği, çalışma karşılığında kazanılan gelirin kendisinin ve/veya ailesinin insan onuruna yakışır biçimde yeterli gelir elde edememesi durumunu açıklarken, temsil güvencesizliği ise sendikalaşma hakkının tanınmaması, sendikal hakların kullanılması konusundaki hukuki koruma eksikliği ve işçilerin çalışma koşulları, ücret ve diğer işyeri/işletme içerisinde karar süreçlerinde yer almamaları şeklinde ifade edilmektedir. Sendikaların içsel ve dışsal nedenlerden dolayı örgütlenmesi veya toplu sözleşme/pazarlık süreçlerinde ortaya çıkan problemleri de açıklamakta ve genişletmektedir. Sosyal güvencesizlik ise genel sağlık, iş kazası ve meslek hastalığ1, işsizlik sigortası ve emeklilik hakları gibi korumalara erişim sağlanamaması şeklinde ifade edilmektedir (Cranford vd., 2003: 13-15; Temiz, 2004: 59-60; Erdut, 2005: 21-22; Benach vd., 2014: 238). Güvencesizlik yukarıda açıklanan türlerden herhangi birine, tamamına veya farklı kombinasyonlar ile de gerçekleşebilmektedir. Güvencesizlik, salt 
2003: 9-17; Temiz, 2004: 60; Erdut, 2005: 21-22).

Küreselleşme sürecinin hızlanması ve yeni liberal politikaların yaygınlık kazanması, çalışma yaşamına yönelik pek çok gerilemelere yol açacak politika süreçlerini hızlandırmıştır. Bu dönemde, düşük ücret politikası benimsenmiş, kötü çalışma koşullarında ve işsizlik oranlarında artış yaşanmış ve güvencesiz istihdam yayg1n ve kapsamlı bir duruma gelmiştir (Munck, 2013: 751-52; Koray, 2018: 22223). Munck, gerçekleşen bu dönüşümü, küresel ölçekte var olan güvencesiz çalışma gerçeğinin tüm küreye yayılma süreci olarak da ifade edilebileceğini belirtmektedir (Munck, 2002: 5; Munck, 2013: 752).

Gig ekonomisi, kısaca, sosyal ve siyasal yapıdaki dönüşüm ve teknoloji alanındaki ilerlemelerin bir sonucu olarak ortaya çıkmıştır. Bu bağlamda, gig ekonomisi, işgücü piyasasında daha önce var olan güvencesiz istihdamın bir uzantısım oluşturmamaktadır (Woodcock ve Graham, 2020: 63). Gandini, gig platformlarının daha önceki güvencesiz istihdam modellerinden farkını ise kısaca şu şekilde özetlemektedir. Gig ekonomisi platformları, mevcut yönetim yapılarından farklı olarak, teknolojinin getirmiş olduğu yenilikler ile birlikte, görünmeyen algoritmalar aracılığıyla çalışanlarını denetlemekte, çalışanlarını rekabetçi bir konuma dönüștürmekte ve işyeri pazarlık gücünü minimize ederek, sendikalaşmay1 zorlaştıran ve çalışanları bireyselleştiren yeni bir süreç olarak özetlenebileceğini belirtmektedir (Gandini, 2019: 1051-1052). Böylelikle, hem yerel düzeyde, hem de çevrimiçi gig ekonomisi platformlarında gerçekleşen iş ilişkilerinde, yetki ve sorumluluk platformlar tarafından oluşturulan algoritmalara devredilmektedir. Bu durum daha önce meydana gelen güvencesiz istihdam modellerinden farklılaşmasına da neden olmaktadır. Ancak, gig işçilerinin güvencesizlik türlerine çok boyutlu ve kapsamlı biçimde maruz kaldıkları bilinen bir gerçektir (Muntaner, 2018: 598; Chen, 2020: 126-127; Woodcock ve Graham, 2020: 16-17). Öncelikle, gig ekonomisi platformları kendilerini işveren yerine "aracı bir yapı", işçileri ise yanlış bir sınıflandırma ile "bağımsız yüklenici" olarak nitelendirmekte ve bu durum işçilerin aşırı eğreti (hyper precariousness) istihdama maruz kalmalarını hızlandirmakta ve güvencesiz istihdamın artışına da aracilık etmektedir (Johnston ve Land-Kazlauskas, 2019: 3). Esasen, yanlış sınıflandırmanın işgücü piyasasındaki yansıması ise "esnek işgücü-güvencesizlik" biçiminde meydana gelmektedir" (Todoli-Signes, 2017: 199; Larsson ve Sabolová, 2020: 176-77).

Gig platformlarında yer alan işçilerin yukarıda belirtilen beş temel (iş, istihdam, gelir, temsil ve sosyal koruma) güvencesizlik türünün herhangi birine,

çalışma yaşamını değil, yaşamın tüm alanlarını etkileyen bir süreci de oluşturmaktadır (Kallaberg, 2009: 9-10).

7 İşü̈cü piyasasında esnek istihdam modellerinin yaygınlık kazanması sonucu, ortaya çıkabilecek ekonomik ve sosyal risklere karşı koruyucu düzenlemelerin olmadığ takdirde, emek ile sermaye arasındaki güç dengesi sermaye lehine olacaktır. Böylece, sermaye artık değere yoğun biçimde sahip olurken, işçiler ise yaşamlarının tüm alanlarını kapsayacak güvencesizlik riski ile karşı karşıya kalacaktır (Aykaç, 2018: 152). 
tamamına veya farklı kombinasyonları ile karşılaştıkları yapılan çalışmalarda da gözlenmektedir. Bu doğrultuda, daha önce de belirtildiği gibi gig iş̧̧ilerinin güvencesizliklerini derinleştiren en önemli unsur ise, taraflar arasında kurulan iş ilişkisinin yanlış sınıflandırılmasıdır (Donovan vd., 2016: 8; Johnston ve LandKazlauskas, 2019: 3; Tassinari ve Maccarrone, 2020: 49-50). Örneğin, İtalya'da Foodora işçilerinin çıktığı grevin ardından açıklama yapan firma yöneticisi, yapılan işin "gerçek bir işten çok, bisiklete binmeyi sevenler için bir miktar para kazanma yolu" olarak ifade etmiştir (De-Stefano, 2018: 69). Bu bağlamda, platformların işçileri bilinçli olarak yanlış sınıflandırması, başta sosyal güvenlik, iş, istihdam, gelir ve temsil güvencesizliğini meydana getirmekte ve işgücü piyasasını ilgilendiren hukuki süreçleri etkilemektedir (Dokko, 2015: 2; De Stefano, 2016a: 463; Katta, vd., 2020: 204; Tassinari ve Maccarrone, 2020: 38).

Gig ekonomisi içinde hem talep üzerine, hem de çevrimiçi platformlarda istihdam edilen işçilerin, güvencesizlik durumları birkaç türde meydana gelmektedir. Öncelikle, gig ekonomisinde gerçekleştirilen işler "iş güvencesizliğinin" temelini oluşturmaktadır (Graham vd., 2017: 6-19). Gig platformlarında gerçekleştirilen işler genellikle kısa süreler (tek sefer/lik) içerisinde tamamlanmakta (Friedman, 2014: 171; Graham vd., 2017a: 4; Schafer ve Schwarzkopf, 2019: 2) ve platformlar tarafindan tek taraflı uygulanan, puanlandırma, sınıflandırma ve derecelendirme kriterlerine erişemeyen işçilerin, hizmet sözleşmeleri platformlarca sona erdirilmektedir (De Stefano, 2016a: 463; Aloisi, 2016: 674; Graham vd., 2017: 6-7; Todoli-Signes, 2017: 196 Gandini, 2019: 1049-50). Gig işçileri, platform algoritmaları aracillğıyla hizmet sözleşmelerinin sona erdirilmesine yönelik yaptıkları hukuksal başvurular ise, yanlış sınıflandırma nedeniyle hukuki süreçlerin uzamasina yol açmakta (mahkemeler tarafindan sınıflandırmanın tekrardan yapılma süreci) veya sonuç alınamamasına neden olmaktadır (Friedman, 2014: 171; Aloisi, 2016; Lobel, 2017: 6-14).

Gig ekonomisinde, akıllı cep telefonu uygulamalar1 ve/veya internet siteleri aracılığıyla kurulan iş ilişkileri genellikle kısa süreler içerisinde tamamlanmaktadır. Bu bağlamda, gig işçileri, tamamladıkları her iş karşılly̆ında ücret kazancı elde etmektedir (Donovan vd., 2016: 1-2). Ancak gig işçileri tarafindan tamamlanan işler sonucu elde edilen ücret düzeyinin ise yeterli miktarda olmadığ yapılan çeşitli araştırmalarda da vurgulanmaktadır (Stewart ve Stanford, 2017: 423 ; Flanagan, 2019: 63; Wood, vd., 2020: 75; Erdut, 2021: 49). Bu durum, gig işçilerinin gelir güvencesizliğine maruz kaldıklarının göstergesidir. Böylelikle, gig işçileri kendisinin ve/veya ailesinin insan onuruna yaraşır bir yaşam sürdürmelerini sağlayacak gelir elde edebilmesi için daha fazla çalısma gerekliliğini ortaya çıarmaktadır. Aksi takdirde elde edilen gelirin/gelirlerin yeterli düzeyde olmayacağ1 da bilinmektedir (Aloisi, 2016: 662; DeStefano, 2016a: 463; Risak, 2017: 3; Manriquez, 2019: 183-184).

Gig işçilerinin yanlış sınıflandırılmasının ortaya çıkardığı diğer sorun alanı ise temsil güvencesizliğini yaratmasıdır. Yukarıda ifade edildiği üzere, işçilerin, platformlar tarafindan bilinçli olarak yanlış sınıflandırılması, meydana gelen 
ekonomik ve sosyal risklerinin yanında, örgütlenme, toplu pazarlık ve grev hakkının kullanımını da engellemektedir. Böylece, sendikalaşma ve toplu sözleşme hakkına erişim sağlayamayan gig işçilerinin pazarlık güçleri zayıflamakta ve temsil güvencesizliğinin ortaya çıkmasına neden olmaktadır. Gig işçileri, çalışma koşulları, ücret ve diğer işyeri süreçlerine katılımlarının sağlama konusunda yer almamaları temsil güvencesizliğini derinleştirmektedir. İngiltere'de, Büyük Britanya Bağımsız İşçiler Sendikası (IWGB) Deliveroo işçilerine yönelik toplu sözleşme sürecini yürütmek istemiştir. Bu doğrultuda, Merkezi Tahkim Komitesi'ne (CAC) başvuran işçi sendikası, toplu sözleşme için yetki alamamıştır. Bu karara itiraz eden işçi sendikası kararı üst kurula götürmüş, ancak yetki belgesini yine alamamıştır. Temsil güvencesinin hukuki olarak tanınmaması, gig işçilerine başka mekanizmalar aracılı̆̆ıyla örgütlenme girişimlerine mecbur bırakmaktadır. ABD'de ve Avrupa ülkelerinde çeşitli işçi derneklerinin ve kooperatiflerin, platformlar karşısında kolektif bir güç oluşturma amacıyla kurulduğu da bilinmektedir (Johnston ve LandKazlauskas 2019; Chen, 2020: 135-139).

Gig ekonomisi platformlarının hızlı büyümesi ve küresel işgücünde kalıcı bir duruma yerleşmesi, bireylerin en önemli haklarının başında gelen sosyal güvenlik hakkını tehlikeye atmaktadır (Erdut, 2021: 52). Gig platformları genellikle çalışanların, genel sağlık sigortası, işsizlik sigortası, iş kazası ve meslek hastalıkları primlerini ve hafta tatili ve yıllık ücretli izin haklarını karşılamamaktadır (Bajwa vd., 2018: 2; Larsson ve Sabolová, 2019: 177). Böylece, gig işçilerin karşılaş̧tıları bu süreç, çalışma yaşamı içerisinde veya çalışma yaşamı sonrasındaki sürece etki etmektedir. Larsson ve Sabolová, ABD'deki sosyal güvenlik sorununa dikkat çekerek, vatandaşların yüzde 54'ünün (Carter, 2018) sağlık hizmetlerini finanse edemediklerini, gig ekonomisinin yangınlaşmasıyla beraber bu durumun daha da artacağını ileri sürmektedir (2019: 177). Bu bağlamda, gig ekonomisi platformlarının başta sosyal güvenlik olmak üzere çalışma yaşamını ilgilendiren koruyucu düzenlemeleri yerine getirmemesi, hem bireylerin sosyal koruma mekanizmalarından yoksun kalmasına yol açacak, hem de ulus devletlerin vergi kaybina neden olacaktır.

\title{
Neo-Liberalizmin Girişimci İdeolojisi: UBER
}

\author{
"Uber internet sitesine göre, 2008 yllının karlı bir Paris akşamında, \\ Travis Kalanick ve Garrett Camp taksi çağırırken sorun yaşadılar. \\ Böylelikle basit bir fikir buldular: Bir düğmeye dokunun [ve] bir \\ gezintiye çııın" (Ravenelle, 2019: 49).
}

Uber, talep üzerine gig ekonomisi platformları içinde küresel olarak en yaygin bilinen firmaların başında gelmektedir (Aloisi, 2016: 672; Khreiche, 2018: 45; Woodcock ve Graham, 2020: 75). Uber'in iş organizasyonunun çoğu zaman gig ekonomisinin işleyişiyle eş anlamlı kullanıldığı bilinmektedir (Katta, vd., 2020: 204). Uber, geleneksel yolcu taşıma hizmetini, tüketici davranışlarının farklılaştığı, 
internet ve akıllı cep telefonu kullanımının artış gösterdiği ve işgücü piyasalarında ekonomik ve sosyal risklerin çalş̧anlara devredilmek istendiği bir süreçte ortaya çıkan, "yenilikçi” olduğu ileri sürülen bir firmadır (Stanford, 2017: 386). 2021 y1lı itibariyle, 70 ülkede ve 900'den fazla merkezde faaliyet göstermektedir (Uber, 2021a). Uber'in iş organizasyonu çerçevesinde 22 bin çalışanı ve kendisi için çalışan, ancak, "çalışan" yerine "ortak" olarak sınıflandırdı̆̆ 3 milyon 900 bin sürücüye de platformda yer alma hakk1 vermektedir (Uber, 2021b). Ayrıca, 2021 yll Mart ayındaki borsa değeri ise 103 milyar dolar seviyesindedir (Yahoo Finance, 2021).

2009 yllında kurulan Uber, 2010 yllında San Francisco'da, taşıma hizmeti lisansl1, yüksek kaliteli, siyah renk arabalar ve limuzin araç modelini içeren ve çalışanların sigortalı olduğu UberCab modeli ile taksi endüstrisine dâhil olmuştur (Collier vd., 2017: 11; Schmidt, 2017: 20). Taksi endüstrisine yeni dâhil olan UberCab, sürücülerin tepkileri ve Kaliforniya'daki "yasal itirazın” ardından 2011 yllında ismini Uber olarak değiştirmek zorunda kalmıştır (Cornelissen ve Cholakova, 2019: 3). Bununla birlikte, Uber'in piyasaya sürdüğü ilk modelin, hem yüksek kaliteli bir hizmet olması nedeniyle yaygınlı gösterememesi, hem de 2012 yllinda kurulan Lyft ve SideCar ile rekabet etmek amaciyla, daha ucuz modeli olan UberX'i 2012 yılında piyasaya sürmüştür (Aloisi, 2016: 672; Collier vd., 2017: 11).

UberX, sürücülerin sahip olduğu binek araçların kullanıldığı, sürücülerin "bağımsız yüklenici" olarak sinıflandırıldığ ve yerel taksi hizmetlerinden daha düşük fiyat politikasının benimsendiği bir modeli ifade etmektedir (Schmidt, 2017: 20; Woodcock ve Graham, 2020: 76). Uber zaman içinde, hem yolcu taşımacilı̆ıında, hem de yemek teslimatı, taşımacılık ve diğer hizmet alanlarında da çeşitliliğe gitmiştir. Uber, yolcu taşımacıllğında, kalabalık gruplar için sportif çok amaçlı araç (SUV) veya minibüsün kullanıldığ1 UberXL modeli ve lüks yolculuk yapmak isteyenler için ise UberBlack modeli bulunmaktadır (Cornelissen ve Cholakova, 2019: 3-4; Woodcock ve Graham, 2020: 77).

Uber'in iş organizasyonu kısaca açıklanacak olursa, aşağıdaki süreç şeklinde meydana gelmektedir. Müşteri ilk olarak, Uber tarafindan daha önce oluşturulan mobil uygulamay1 (created mobile application), ak1llı cep telefonuna indirir ve hesap oluşturur. Ardından, müşteri oluşturmuş olduğu hesabına, kredi kart1 bilgilerini kayıt eder (Aloisi, 2016: 672; Deon, 2020: 197). Böylece, A noktasından B noktasına gitmek isteyen müşteriler önce rotasını belirlemekte, sonra yolculuk etmek istedikleri araç modelini seçmekte ve son olarak ise GPS verileri aracıllğıyla konumuna en yakın sürücüler ile eşleştirilmektedir (Manriquez, 2019: 169). GPS teknolojisi, müşteriye yolculuk ücretini ve varış zamanlarını da tahmini olarak hesaplayarak önceden bildirmektedir (Collier vd., 2017: 13; Deon, 2020: 197). Bununla birlikte, müşteriler, uygulama aracilığıyla sürücülerinin kullanıcı profillerini ve kimlik bilgilerini sistem üzerinden görme imkânına sahiptir (Schmidt, 2017: 20). $\mathrm{Bu}$ doğrultuda, algoritma tarafindan sürücüye yönlendirilen yolculuk talebi, kabul etme veya reddetme seçeneği şeklinde sunulmaktadır. Yolculuk talebinin sürücü 
tarafindan kabul edilmesinden sonra, Uber sürücüsü, müşterinin konumuna gider ve ardindan yolculuk tamamlanır (Aloisi, 2016: 672-673; Todoli-Signes, 2017: 195; Schmidt, 2017: 20). Uber tamamlanan her iş için yüzde 25 (Uber, 2021) oranında komisyon ücreti almakta ve kalan kısmını ise sürücünün banka hesabına aktarmaktadır (Manriquez, 2019: 173).

\section{İş İlişkileri}

Uber, yaklaşık on y1llık geçmişi sahip olmasına rağmen, çok uluslu/ulus ötesi bir şirket konumuna gelmiştir (Deon, 2020: 197). Uber’in 70 ülkede faaliyet göstermesi ve sayılarının 4 milyona yaklaşan bir işgücüne sahip olması (Uber, 2021b), hem gig ekonomisinin hızlı büyümesinin ardındaki olguyu açıklamak amacıyla, hem de iş ilişkilerinde yaratmış olduğu sorunlar nedeniyle incelenmeyi gerekli kılmaktadır. Uber'in büyüme stratejisi ise genellikle, reklam kampanyalarına, sürücülere vaat ettiği çalışma saati esnekliğine, düşük giriş engellerine, düşük fiyat politikasına ve ek gelir sağlama firsatına dayanan politikalar üzerinden gerçekleşmektedir (Aloisi, 2016: 673; Collier vd., 2017: 13; Woodcock ve Graham, 2020: 75; Purcell ve Brook, 2020: 8).

Uber, hem geliştirmiş olduğu iş organizasyonu ile yasal olarak sürücü istihdam etmemekte, hem de işin gerçekleştirilmesi için gerekli araç ve gereçleri satın almamaktadır (Stanford, 2017: 387; Woodcock ve Graham, 2020: 75). Üstelik oluşturmuş olduğu algoritmalar aracilığıla, sürücülerini puanlandırma, derecelendirme ve sıralama mekanizmalarıyla denetim altına almaktadır. Böylece, devasa işgücünü kontrol edecek insan kaynakları yerine, algoritmada depolanan bilgiler doğrultusunda sürücüleri denetlemektedir (Aloisi, 2016: 674; Todoli-Signes, 2017: 196; Schmidt, 2017: 11; De-Stefano, 2018: 72).

Uber'in algoritmalar aracillğıyla işgücü üzerinde kurmuş olduğu hegemonik despotik rejimles sürücülerin iş kabullerinde, sürüş esnasındaki davranışlarında ve içsel

${ }^{8} \mathrm{Bu}$ çalışmada gig ekonomisi platformlarının inşa etmek istediği üretim rejimi açıklamak için Burawoy'un "hegemonik despotik rejim" kavramı tercih edilmiştir. Michael Burawoy "Üretim Siyaseti” (2015) kitabında üretim rejimlerini beş başlık altında sınıflandırmaktadır. Bunlardan ilki patriarkal despotizmdir. Patriarkal despotizmde emek sürecinin kontrolü ailededir. Üretim süreci hane reisi babaya dayanır ve emek süreci üzerinde baba denetime sahiptir. Bu üretim rejimi teknolojik gelişmeler sonucu kadınların ve çocukların işgücüne dâhil olmasıyla zayıflamıştır. İkincisi, paternalist despotizmdir. Paternalist despotizmde, ailenin kontrolünde olan ve patriarkal despotizm olarak nitelendirilen emek süreci, işverenin çıkarları ile yeniden biçimlenir. Üretim süreci üzerindeki egemenlik aileden (babadan) yeni baba suretinde olan sermaye sahibi patrona geçer. Üçüncüsü piyasa despotizmidir. Piyasa despotizmi, kapitalizmin ilk dönemindeki süreci ifade eder. Piyasa despotizmi, firmalar arasında serbest rekabetin olduğu, işçilerin emek süreci üzerinde kontrolünün olmadığ1, devletin piyasaya müdahale etmediği ve işçilerin emeğini satmak zorunda olduğu bir rejimdir. Dördüncüsü hegemonik üretim rejimidir. Hegemonik üretim rejimi, ikinci dünya savaşı sonrası işçilerin sermayeye bağımlılığının devletin uyguladığı sosyal güvenlik ve sosyal 
veya dışsal denetim süreçlerinde başlıca etken olduğu bilinmektedir. Uber, uygulama üzerinden sürücülere yönlendirdiği yolculuk talebini, her ne kadar "kabul etme veya reddetme" şeklinde sunuyor olsa da genellikle tüm sürüşlerin kabul edilmesini istemekte (De-Stefano, 2016: 492; De-Stefano, 2018: 71) veya ya doğrudan ya da dolaylı yoldan taleplerin kabul edilmesine yönelik politikalar uygulamaktadır.

Uber'in, yolculuk isteklerini kabul ettirmek için, doğrudan sürücülere uygulamış olduğu ilk strateji, çevrimiçi zamanı kontrol etme biçiminde gerçekleştirmektedir. Uber sürücüleri, uygulamada aktif oldukları andan itibaren, sistemden yönlendirilen yolculuk taleplerine 15 ile 30 saniye içinde kabul etme veya reddetme şeklinde cevap vermek zorundadir. Aksi takdirde, sistem yolculuk talebini başka bir sürücüye yönlendirmektedir. (Cornelissen ve Cholakova, 2019: 6; Manriquez, 2019: 174). Sürücü, uygulamadan gelen yolculuk taleplerine kabul etmeğinde veya 15 ile 30 saniye aralı̆̆ında geri dönüş sağlamadığında bu geri bildirimler sistem içerisinde depolanmakta ve işlenmektedir (Collier vd., 2017: 12).

Uber, sürücülerin sistemde aktif oldukları zamanı daha yoğun olarak kontrol etmek istemekte ve böylelikle yolculuk taleplerinin kabul edilmesi için de bask1 uygulamaktadır. Uber, sürücüler üzerinde uyguladığı kontrol ve iş kabul baskısını yoğunlaştırmak için ise genellikle yolculuğun tamamlanmasına yakın bir zamanda, sürücülere yeni bir yolculuk talebinin olduğunu belirten bildirimler göndererek gerçekleştirmektedir (Cornelissen ve Cholakova, 2019: 6; Manriquez, 2019: 174). Uber sürücüleri, sistemin yönlendirmiş olduğu yolculuk taleplerine çoğu zaman "reddetme ve/veya cevap vermeme" şeklinde dönüş sağlaması durumunda ise, düşük yolculuk kabul oranlarına neden olacak ve böylelikle sistem tarafindan profilin ya askıya alınmasana ya da devre dışı bırakılmasına yol açacaktır (DeStefano, 2016: 492; Collier vd., 2017: 12; Todoli-Signes, 2017: 195; De-Stefano, 2018: 71; Cornelissen ve Cholakova, 2019: 6).

Uber’in sürücülerin çevrimiçi oldukları zamanı kontrol etmek için uyguladığ1 ikinci strateji ise, sürücüleri sistemde tutmaya yönelik bildirimler gönderme şeklindedir. Örneğin, Uber Florida'da bir sürücüye "330 dolara çıkar" diye bir mesaj bildirimi göndermiştir. "Mesaj daha sonra şölle açılklanyor: net kazançta 330 dolar

politikalarla sınırlandırıldı̆̆ı ve alternatif geçim olanaklarına sahip olduğu rejimdir. Sonuncusu ise hegemonik despotik rejimdir. Hegemonik despotik rejim, 1980 sonras devletin ekonomik ve sosyal alandan geri çekildiği ve piyasanın yeniden ana aktör olduğu bir süreci ifade eder (Özuğurlu, 2008: 49-51). Bu bağlamda, başta Uber olmak üzere gig ekonomisi platformlarının -çalışma boyunca ifade edilen- düzenlenmemesi ve düzenlenmesine yönelik çalışmaların ise birbirinden farklı sonuçlandığı bilinmektedir. Gig firmalarının "bağımsız yüklenici" olarak sınıflandırarak sosyo-ekonomik riskleri işçilere yüklediği, ücretler konusunda dibe doğru yarış politikası benimsediği ve ulus devletlerin platformlara yenilik, girişimcilik ve istihdam fırsatı temelinde yaklaşım gösterdiği bilinmektedir. Bir başka deyişle, bu süreç küreselleşmenin yoğunlaşmasını, kapitalizmin süregelen finansallaşmasını ve neo-liberalleşmesini de yansıtır. 
kazanmaktan 10 dolar uzaktasmı: Cevrimdısı olmak istediğinizden emin misiniz? şeklinde bir soru sormuştur. Ardından, Uber uygulamasinda iki seçenek. bulunmaktaydl: "çevrimdısı ol" ve "sürmeye devam et". Ancak, Uber göndermis olduğu bildirim ile birlikte sürücülerin "sürmeye devam etmesini" istemektedir (Scheiber, 2017; Khreiche, 2018: 52). Uber'in hem sürüş esnasında yönlendirdiği yeni yolculuk talepleri, hem de çevrimiçi kalış süresini uzatmaya yönelik gönderdiği bildirimlerdeki esas sorun, yeni yolculuk talebinin içeriğinin gizli tutulmasıdır. Böylece Uber sürücüsü, yeni yolculuk talebinin kendi çıkarına olup olmadığ Cholakova, 2019: 6).

Uber'in, yolculuk taleplerini kabul ettirmek için "dolaylı" yoldan uyguladığ strateji ise, hizmet ile ilgili giderlere karışmama politikası ileri sürülebilir. Uber, hem hizmetin gerçekleştirilmesi için gerekli aracın satın alımında veya kiralanmasında, hem de yolculuk esnasındaki akaryakıt giderlerini, aracın sigorta, bakım ve kasko maliyetlerini karşılamamaktadır. Üstelik Uber, sürücülerini "çalışan” yerine "ortak" olarak sınıflandırdığını ileri sürerek, genel sağlık sigortası primlerini yatırmamakta ve iş sağlığı ve güvenliği önlemlerini dikkate almamaktadır. Bunların yanında, sürücülerin asgari ücret ve fazla çalışma ücreti gibi haklarına da karışmamaktadır (Schmidt, 2017: 20; Todoli-Signes, 2017: 195; Stanford, 2017: 387; Cornelissen ve Cholakova, 2019: 6; Manriquez, 2019: 174). Uber'in sürücülerin ekonomik ve sosyal temelli haklarını karşılamamasının ve sürüş ile ilgili giderlere karışmama politikasının, doğrudan yolculuk talepleri ile ilgili olmadığ söylenebilir. Ancak, sürücülere devredilen, sosyal güvenlik masraflarının karşılanabilmesi, araç giderlerinin ödenebilmesi ve yeterli gelirin kazanılabilmesi için sürücülerin daha uzun saatler çalışma zorunluluğunu ortaya çıkarmaktadır9. Böylelikle, Uber geliştirmiş olduğu algoritmalar aracillğıyla sistem içerisinde tutma, giderlere karışmama ve çeşitli bildirim gönderme şeklinde uyguladığ1 stratejiler ile sürücüler üzerinde zora dayalı bir kabulü inşa etmektedir.

Uber geliştirmiş olduğu algoritmalar aracılı̆̆ıyla, sürücüleri doğrudan değil, müşterileri değerlendirmeleri üzerinden denetlemektedir. Bir başka ifadeyle; sürücülerin denetimini içsel denetiminden koparıp, dış denetim konumundaki müşterilere devretmektedir. Uber, her yolculuk sonrası müşterilerden, sürücüleri 1 ile 5 puan arasında bir puan ile değerlendirmelerini istemektedir. Böylece Uber, yolcuların değerlendirmeleri ile sürücülerin kendi bünyesinde çalışmaya devam edip etmeyeceğine karar vermektedir. Müşterilerin sistem üzerinden gerçekleştirdiği hizmet değerlendirme puanlandırması sonrası, sürücülerin 4,5 ila 4,7 puan arasında

9 Örneğin, Meksika'da Uber sürücüleri ile yapılan araştırmada bu durum şöyle ifade edilmiştir: "Sürücüler, uygulamada ne zaman oturum açacakları ve kapatacakları kontrolün keyfini çıkaramadılar ve günün sonunda makul bir gelir elde etmek için genellikle uzun saatler boyunca (8 ila 16 saat) çalışmak zorunda kaldılar." Bir diğer örnek ise; "Sadece 10 saat çalışıyorum, arabası olmayan insanlardan biraz gelir elde edebilmek için günde 16 saat çalışmaları gerektiğine dair korkunç hikâyeler duyuyorum" şeklinde geri dönüşler sağlanmıştır (Manriquez, 2019: 182-183) 
değişen bir aralıktan az bir puana sahip olmamaları gerekmektedir. Aksi takdirde, Uber'in sürücülerin profillerini ya askıya alması ya da devre dişı birakması beklenmektedir (Aloisi, 2016: 674; Lobel, 2017: 7; Manriquez, 2019: 174; Woodcock ve Graham, 2020: 116).

$\mathrm{Bu}$ bağlamda, denetimin gig platformlarından müşterilere devredilmesi, sürücüler üzerindeki baskıyı daha da yoğunlaştırmaktadır. Üstelik gig platformlarının, marka değerlerini korumak ve müşteri memnuniyetini sağlamak amaciyla gig işçilerine çeşitli konularda talimatlar verdiği de bilinmektedir (Donovan vd., 2016: 3). Örneğin, Uber’in sürücüler için hazırlattığ1 kullanım kılavuzunda, müşterilerin kapılarmın açılmasım, arabalarında yağmurlu günler için semsiye bulundurmalarme, radyonun tamamen kapatılmasinı veya salt caz mürike calinmasin ve önceden belirlenen kiyafet kurallarna da uyulmasinı istemektedir (Todoli-Signes, 2017: 195).

Uber sürücülerinin, yolculuk esnasinda belirtilen kurallara uymasi ve müşteriler tarafindan derecelendirmeye tabi tutulması duygusal emek sorununu da ortaya çıarmaktadır. Yolculuk hizmetinin gerçekleşmesinin ardından, müşterilerin sürücüleri derecelendirmesi, sürücülerinin yolculuk esnasında müşteriler ile girdikleri sosyal etkileşimi önemli kilmaktadır. Bu durumun temelinde, Uber uygulaması üzerinden yapılan 1 ile 5 puan arasındaki değerlendirmenin sonucunda, sürücülerinin çalışmaya devam edip etmeyecekleri endişesi yatmaktadır. Uber sürücüleri, müşteriler tarafından gerçekleştirilen derecelendirmeyi kendi lehlerine çevirmek için, araca binerken kapılarını açmak, araçta su bulundurmak, müşterilere karşı güler yüzlü olmak gibi istemli veya istem dışı çeşitli girişimlerde bulundukları da bilinmektedir (Gandini, 2019: 1063-5; Manriquez, 2020: 176; Purcell ve Brook, 2020: 9-10).

Yukarıda ifade edildiği gibi Uber’in hem kısa zaman aralığında küresel ölçekte yaygınlık kazanması, hem de Uber sürücülerinin bağımsız yüklenici olarak sınıflandırılması pek çok sorunun ortaya çıkmasına da neden olmaktadır. Bu doğrultuda, son yıllarda ulus devletlerde ve bölgesel kuruluşlarda, iş hukuku, sosyal güvenlik hukuku ve çalışma yaşamını ilgilendiren diğer konularda ve hatta rekabet hukuku alanında da düzenleme yapma gereksinimini doğmaktadır. Bu bağlamda, Uber sürücülerinin sınıflandırılmasına yönelik, politika yapıcılardan, sivil toplum kuruluşlarından, akademisyenlerden, işçi sendikalarından, işveren örgütlerinden pek çok farklı düzenleme görüşünün olduğu da bilinmektedir. Bu durum, sosyal taraflar arasındaki görüş farklılıkları ulusal veya uluslararası yarg1 kararlarında da gözlenmektedir. Nitekim, küresel ölçekte aynı hizmeti gerçekleştiren Uber sürücüleri, Fransa'da ve İngiltere'de “işçi” olarak tanımlanırken, ABD'de, Belçika'da ve Güney Afrika'da "bağımsız yüklenici” olarak nitelendirilmektedir. Bu bağlamda, Uber sürücüleri aleyhine ve lehine sonuçlanan mahkeme kararları aşağıda incelenecektir. 


\section{Uber Sürücüleri Aleyhine Sonuçlanan Mahkeme Kararları}

Sürücülerin "işçi” yerine "bağımsız yüklenici” olarak nitelendirilme tartışmasına yönelik, başta ABD'de olmak üzere pek çok ülkede yargisal sürecin devam ettiği bilinmektedir (Berry, 2021). Bu anlamda, 2013 yllında, Uber'in çalışanlarını "bağımsız yüklenici" olarak sınıflandırmasına yönelik "Douglas O'Connor ve Hakan Yucesoy" tarafindan Kaliforniya ve Massachusetts eyaletlerinde iki sınıflandırma davası açılmıştır (Isaac ve Scheiber, 2016). Bu davalar toplamda 385 bin Uber sürücüsünü ilgilendirmekteydi (Zwick, 2018: 685). 2013 yllında açılan sınıflandırma davasındaki temel gerekçe, Uber sürücülerinin "bağımsız yükleniciler" olarak mi, yoksa "işçi” olarak mı sınıflandırılıp sınıflandırılmayacağının tespit edilmesine yöneliktir (Court of Appeals, 2018). Uber, tarafina açılan sınıflandırma davaları için toplam $100(84+16)$ milyon dolar ödeme yapacağını ve her iki eyalet için de "sürücü dernekleri/drivers associations" kuracağını beyan ederek davayı kazanmıştır (Isaac ve Scheiber, 2016a; Wong, 2016). Böylece Uber, hem Kaliforniya ve Massachusetts eyaletlerdeki sürücülerini "bağımsız yüklenici" olarak sınıflandırmayı kaybetmemiş, hem de kararın başka eyaletlerde benzer davaların açılmasını da engellemiştir (Casetext, 2021).

Diğer taraftan, ABD'de yolcu taşıma hizmetlerine yönelik en önemli sayllabilecek düzenleme girişimi ise 2019 yıllnda Kaliforniya eyaletinde gerçekleşmiştir. Kaliforniya Eyalet Meclisinin işgücü piyasasındaki çalışanları sınıflandırmak için kullandığı $\mathrm{ABC}$ testinde değişikliğge gitme kararı almıştır. Böylece, ABC testinde yapılan Meclis Tasarıs1-5 (Assembly Bill-5) veya AB-5 düzenlemesi sonrası, taksi işkolunda faaliyet gösteren Uber ve Lyft sürücülerinin, "bağımsız yüklenici" yerine "işçi” olarak yeniden sınıflandırılması gerekliliği de ortaya çıkmıştır (Siddiqui, 2020). Bu değişiklik sonrası, Uber ve Lyft sürücüleri, iş ve sosyal güvenlik hukukundaki koruyucu düzenlemelere hak kazanmışlardır. Böylelikle, Uber ve Lyft sürücüleri, asgari ücret, sağlık sigortası ve işyerinde ayrımcıllğın yasaklanması gibi haklara sahip olma firsatı doğmuştur (Legislative Analyst's Office, 2020). Ancak, Uber ve Lyft, Kaliforniya Eyalet Meclisinin işçi sınıflandırma testinde yapmış olduğu AB-5 düzenlemesine karşı çıkmış ve bu kararı referanduma götürmek için yoğun bir çaba harcamışlardır. Bu doğrultuda, "Uber, Lyft, DoorDash, Instacart ve Postmates", gibi gig firmalar1 referandumda uygulama aracilı̆̆ıyla çalışanların "işç" değil, "bağımsız yüklenici" olarak sinıflandırılmalarının devam etmesi için yaklaşık 200 milyon dolar harcama yapmışlardır (O'Brien, 2020). "2020 Kaliforniya Önerisi-22” veya Prop-22 olarak isimlendirilen ve 3 Kasım 2020 tarihinde yapılan referandumda yüzde 58 oranında "işçi" olarak değil, "bağımsız yüklenici" olarak sınıflandırma kararı çıkmıştır (Ballotpedia, 2021). Bu karar, başta Uber ve Lyft sürücüleri olmak üzere gig işçilerinin asgari ücret hakkı, ücretli tatil hakk1, dinlenme hakk1, sosyal koruma hakkından yoksun bırakılmalarına neden olmaktadır. 
Böylece, Eyalet Meclisinin çalışanların sınıflandırılması için kullandığı ABC testinde yapmış olduğu AB-5 düzenlemesi referandum sonucu reddedilmiştir. Eyalet Meclisinin çalışma yaşamını ilgilendiren düzenlemesinin referanduma götürülmesi, doğrudan demokrasinin güçlendirilmesi açısından olumlu bir örnek teşkil etse de, esasen vatandaşların bireysel tercihlerinin, çalışanların temel hakları aleyhine sonuç yaratabileceği olasıllı̆ının da unutulmaması gerekmektedir. Bireylerin tüketici alışkanlıklarının oy verme davranışlarını etkilemesi de beklenmektedir. Nitekim, gig çalışanlarının "işç’" olarak yeniden sınıflandırılması, tüketicilerin hizmetlere mevcut ücret düzeyinden daha yüksek ödeme yapmalarına neden olacaktır. Bu bağlamda, 2020 Kaliforniya Önerisi-22 (Prop-22) gibi çalışma yaşamını ilgilendiren düzenlemelerin referanduma götürülmesi yerine, evrensel temel sözleşmelerin dikkate alınarak gerçekleştirilmesi büyük önem taşımaktadır. Aksi takdirde, gig firmaları tüketicilerin tercihleri ile politika yapıcıların meclis kararlarını boşa çıkarabilir -referandum- veya kararlarını etkileyebilir. Böylece, çalışanları ilgilendiren ekonomik ve sosyal hakların yerine getirilememesine veya geriletilmesine neden olabilecek daha büyük sorunlara da yol açabilir.

Uber sürücülerinin sınıflandırılmasına yönelik bir diğer karar ise Avrupa Birliği üyesi Belçika'da verilmiştir. Uber, Brüksel'de UberPop ve UberX modeli ile faaliyet yürütürken, 2014 yılında Brüksel Hareketlilik ve Bayındırlık Bakanı (Brussels Minister of Mobility and Public Works) Pascal Smet tarafindan haklarında suç duyurusunda bulunulmuştur (The Brussels Times, 2017). Ancak, Brüksel savc1llğı bilgi eksikliğini işaret ederek suç duyurusunu reddetmiştir. Uber'in Brüksel'deki faaliyetleri 2015 ve 2016 y1llarında sonuçlanan yarg1 kararları ile yasa dışı olarak nitelendirilmiştir. Ancak, bu karar UberPop için geçerli olmuş ve faaliyetlerine son verilmiştir. UberX modeli ise faaliyetlerine kaldığ1 yerden devam etmiştir (European Commission, 2020: 112).

UberX modelinin faaliyetine devam edip etmeyeceğine yönelik yarg1 kararı ise 2019 yılının Ocak ayında açıklanmıştır. Brüksel yargısı Uber'in ulaşım mevzuatını ihlal etmediğine yönelik kararını açıklamıştır. Bu karar ile birlikte, Uber'in yerel ulaşım "mevzuatını ihlal etmediğine ve sürücülerinin taksi sürücüsü ehliyeti" almak zorunda kalmadan hizmetlerine devam edebileceğine karar kilmıştır. Böylece, UberX modeli bir nakliye "hizmeti olarak değil, taşımacılık sektöründe bir aracı olarak kabul edilirken, sürücülerin" kendileri ile ilgili hizmetlerin sağlayıcıları (providers of the services) olarak kabul edilmiştir. $\mathrm{Bu}$ doğrultuda, Uber sürücülerinin Avustralya'da ve ABD'de olduğu gibi bağımsız yüklenici olarak sinıflandırılmaları karar1 verilmiştir (European Commission, 2020: 112-113).

Brüksel hükümeti ile Uber arasında, sürücülerin çalışma ve ücret koşulları hakkındaki düzenleme çatışması ise güncelliğini korumaktadır. 2021 yılında Belçika hükümeti İş İlişkileri İdari Komitesi, bir Uber sürücüsünün "serbest meslek" statüsüyle uyumlu olmadığını belirtmiştir (ETUC, 2021). Pascal Smet ise Uber'in "çalışma ve ücret koşullarına uyulmasını ve sürücülerin adil bir [istihdam] statüsüne sahip olmasını sağlamak için Brüksel taksi uygulamasının geliştirilmesini 
destekleyin" şeklinde bir açıklama yapmışır (Lyons, 2021). Esasen, Pascal Smet'in açılaması tekelleşen ve çalışanların yasal haklarını zorlaştıran gig platformlarına yönelik işçi kooperatifçiliğini ve ulusal hizmetlerin desteklenmesi görüşünü de yansitmaktadir.

Uber sürücülerinin sınıflandırılmasına yönelik en farklı yarg1 kararı ise Güney Afrika'da gerçekleşmiştir. Uber uygulamasında profilleri devre dışı bırakılan sürücüler, Güney Afrika Ulaştırma ve Müttefik İşçi Sendikası (South African Transport and Allied Workers Union - SATAWU) aracillğıyla Uzlaştırma, Arabuluculuk ve Tahkim Komisyonu'na (Commission for Conciliation, Mediation and Arbitration) başvurmuştur. SATAWU, Uzlaştırma, Arabuluculuk ve Tahkim Komisyonu'ndan Uber sürücülerinin "işçi” olarak yeniden sınıflandırılmasını ve iş hukukundan doğan ekonomik ve sosyal hakların sürücülere tanınmasını talep etmiştir. Uber, SATAWU'nun yapmış olduğu yeniden sınıflandırma başvurusuna itiraz etmiş ve kararı iş mahkemesine taşımıştır. İş mahkemesi, işçi sendikasının başvuru talebinin yanlış olmadığını ancak, açılan davanın Hollanda merkezli "Uber BV'e" yönelik açılması gerekliliğini de belirtmiştir (Woodcock ve Graham, 2020: 190).

İş mahkemesinin vermiş olduğu bu kararın temelinde, hem Uber International Holding BV'nin Hollanda merkezli bir firma olmas1, hem de kullanılan uygulama yazılımının aynı firmaya kayıtlı olması gerçeğinin yattığ1 belirtilmektedir. Güney Afrika'da bulunan Uber-SA'nın ise "sadece sürücüleri kontrol etmek ve destek sağlamak" amaçlı hizmetler sunduğu ifade edilmektedir. Güney Afrikalı Uber sürücülerinin "Uber SA" yerine Hollanda merkezli "Uber BV" ile platformu kullanma ve kurallara uyma sözleşmesi” bulunması nedeniyle, Güney Afrikalı Uber sürücülerinin açacakları davaların Hollanda'da açılması gerekliliği doğmuştur. Uber'in pek çok farklı merkezden faaliyet yürütmesi, kendisini bağlayacak yerel hukuki sorumluluklardan ve vergi düzenlemelerinden kaçmak için de etkin bir araç olarak kullandığ 1 da bilinmektedir (Woodcock ve Graham, 2020: 190-191).

\section{Uber Sürücüleri Lehine Sonuçlanan Mahkeme Kararları}

Uber sürücülerinin "bağımsız yükleniciler" olarak değil, "işçi”" olarak yeniden sınıflandırılmaları açısından en önemli yargı kararı ise 2021 yllında Birleşik Krallık Yüksek Mahkemesinde karara bağlanmışır. Yüksek Mahkemenin vermiş olduğu karar öncesi hukuki süreç kısaca özetlenecek olursa, aşağıdaki şekliyle gerçekleşmiştir.

Öncelikle, 2016 yllinda, Yaseen Aslam ve James Farrar tarafindan yolcu taşıma hizmeti gerçekleştiren Uber'in, başta asgari ücret ve hafta tatili ücreti, kıdem ve ihbar tazminatı gibi hakları sağlamadığını ve Birleşik Krallık iş kanununu ihlal ettiği ileri sürülerek iş mahkemesine tespit davası açılmıştır. Uber, Aslam ve Farrar tarafindan kendisine açılan tespit davasına itiraz etmiş ancak davayı kaybetmiştir. Böylece, Uber sürücülerinin iş hukukundan doğan, asgari ücret, hafta tatili ücreti ve 
diğer temel haklardan yararlanma olanağı doğmuştur (Stewart ve Stanford, 2017: 424).

Bununla birlikte, iş mahkemesinin Uber sürücülerini "işçi" olarak sınıflandırma kararına karşı çıkan Uber, davayı temyiz mahkemesine taşımıştır. Ancak, temyiz mahkemesi de "Londra'daki Uber'in ortak bir platform ile birbirine bağlanmış 30 bin küçük işletmenin bir mozaiği olduğunu fikrini biraz saçma olduğunu" ifade ederek Uber'in yapmış olduğu itirazı reddetmiş ve iş mahkemesinin vermiş olduğu kararı onamıştır (Employment Appeal Tribunal, 2017: 20; De-Stefano, 2018 : 70; Woodcock ve Graham, 2020: 73; Deon, 2020: 199). Temyiz Mahkemesi, Uber'in “... sürü̈üler ile görüsmeler gerçeklesstirilerek işe aldiğm, yolculuk ü̈retini sabitleyerek sürücülerin yolcular ile daha yü̈ksek bir meblağ üzerinde anlaşma sağlanmasm önlediğini, yolculuk ile ilgili bilgilerin sürü̈ülerden gizllendiğini, sürücüleri ilgilendiren şartlarm tek tarafl olarak düzenleme yetkisini kullandiğmı, sürücülere işslerini nasıl yapacaklar konusunda talimatlar verdiğini ve çeşitli şekillerde görevlerini yerine getirirken onlar kontrol ettiğini" belirterek, bu bağlamda taraflar arasında ortaya çıkan iş ilisskisi dikkate alındığında sürücülerinin "işç" olarak nitelendirilmesine karar kılmıştır (Employment Appeal Tribunal, 2017: 21-22, Deon, 2020: 200).

$\mathrm{Bu}$ kararı benimsemeyen Uber, önce iş mahkemesinin, ardından temyiz mahkemesinin vermiş olduğu kararları lehine çevirmek için davayı Birleşik Krallık Yüksek Mahkemesine taşımıştır. Yüksek Mahkeme daha önce hem iş mahkemesinin, hem de temyiz mahkemesinin kararlarını tekrarlayarak, Uber sürücülerini "işçi” olarak sınıflandırılması gerekliliğine karar vermiştir. Yüksek Mahkeme açıklamış olduğu kararı ise 5 temel madde ile gerekçelendirmiştir (Supreme Court, 2021: 28-31). Buna göre;

1- Uber tarafindan yolculuk ücretinin tek taraflı olarak belirlendiği ve sürücülerin yolculuk ücretlerinin belirlenmesi konusunda söz hakkının bulunmadığ1;

2- Uber, sürücülerin hizmetleri yerine getirdiği sözleşme şartlarını tek taraflı olarak belirlemekte ve bu sözleşme yolculuk esnasında geçerliğini korumaktadır. Böylece, sürücülerin sözleşme üzerinde söz hakkına sahip olmadı̆̆1;

3- Uber sürücüleri, yer ve zaman bakımından çalışma özgürlüğüne sahip olsalar bile uygulamaya giriş yaptıkları andan itibaren, [algoritmalar aracıllğ̆yla] yolculuk talepleri kontrol edilmekte ve kisitlanabilmektedir. Uber, sürücülerden yolculuk talebinin içeriğini gizli tutmakta -yolcu ile buluşma noktasına kadar- ve böylece talebin dolaylı olarak reddedilmesini engellenmektedir. Bunun da ötesinde, sürücülerin yolculuk kabul oranlarının belirli bir düzeyin altına inmesi durumunda, sürücünün "profili belirli bir süre kapatılabilmekte veya sistemden çıarılması sağlanabilmektedir”. Bu bağlamda Uber, hem sürücülerin seçimlerini engellemekte, hem de algoritma aracıllğıyla cezalandırma ve sıralama mekanizmaları ile sürücüleri baskı altında tutabilmekte;

4- Uber, sürücülerin hizmetlerini sunma şekli üzerinde önemli ölçüde kontrol sağlamaktadır. Sürücülerin hizmetin gerçekleştirilmesi için gerekli aracın 
kendi standartlarına uygun olup olmadığını incelemekte ve yolculuk sürecini önceden belirlemektedir. Uber sürücüsü uygulama tarafindan "belirtilen rotayı her ne kadar takip etme zorunluluğu bulunmasa da farklı bir rota üzerinden" varış noktasına gittiği için şikâyet edilebilir ve mali riskler ile karşılaşabilme durumu da bulunmaktadır. Bununla birlikte Uber, sürücülerin yolcular tarafindan derecelendirilmelerini, performanslarını yönetmek ve kendisi tarafindan belirlenen seviyenin altına $[4,5-4,7]$ düşmesi durumunda hizmet sözleşmesini fesh etmek için bir araç olarak kullanılabilmekte;

5- Uber, sürücüler ile yolcular arasındaki iletişimi kısıtlamakta ve bireysel bir yolculuğun ötesine geçebilecek herhangi bir iligkkinin kurulmasin engellemektedir. Sürücülerin, yolcular ile ilgili "iletişim bilgilerini öğrenmesini engelleyecek şekilde yönlendirilmektedir. Aynı şekilde, ücretlerin toplanması, sürücülere ödenmesi ve şikâyetlerin ele alınması, yolcu ve sürücü arasında herhangi bir doğrudan etkileşimi önleyecek şekilde tasarlanmıştır. Ayrıca, sürücülerin kaybolan eşyayı iade etmek dışında yolculuk bittikten sonra bir yolcuyla iletissim bilgilerini paylaşması veya bir yolcuyla iletişime geçmesi Uber tarafindan özellikle yasaklanabilmekte" şeklinde gerekçelendirilmektedir.

İngiltere Yüksek Mahkemesinin açıklamış olduğu karar yukarıdaki beş temel gerekçe ile birlikte değerlendirildiğinde, salt çalışma özerkliği üzerinden değil, işin gerçekleştirilmesi süreci de dikkate alınarak verilmiş bir karar olduğu söylenebilir. Yüksek Mahkemenin kararında, Uber sürücülerinin, gerek yolculuk ücretinin belirlenmesi ve gerekse hizmet sözleşmesinin uygulanmasında söz sahibi olmadıkları anlaşılmaktadır. Diğer yandan, sürücülerin sistemde aktif oldukları andan itibaren Uber tarafindan ileri sürülen çalışma özerkliğinin esasen kaybolduğu ve hizmet üzerinde uygulanan baskının ve kontrolün ekonomik riskleri arttırdığı da bilinmektedir. Bunun yanında, sürücüler ile yolcular arasındaki bağlantının koparılması gibi hizmet sürecinin tamamını ilgilendiren konularda Uber'in belirleyici olması, taraflar arasında "ortaklıktan" ziyade bağımlı bir iş ilişkisinin varlı̆̆ının da kanıtı niteliğindedir.

Birleşik Krallık Yüksek Mahkemesi, Uber kararının 101. Maddesinde "bu faktörler bir araya getirildiğinde, sürücüler tarafindan gerçekleştirilen ve Uber uygulaması üzerinden yolculara sunulan ulaşım hizmetinin çok katı bir şekilde tanımlandığ1 ve Uber tarafindan kontrol edildiğı" görülebilmektedir (..) "Sürücülerin bakış açısından, aynı faktörler - özellikle farklı bir hizmet sunamama veya kendi fiyatlarını belirleyememe ve Uber'in yolcularla etkileşimlerinin tüm yönleri üzerindeki kontrolü - mesleki veya girişimcilik becerileriyle ekonomik konumlarını iyileştirme becerilerinin çok az olduğu veya hiç olmadığı anlamına gelmektedir. Sürücülerin kazançlarını artırabilmelerinin tek yolu ise, Uber'in performans ölçütlerini sürekli olarak karşılamaları ve daha uzun saatlerle çalışmalarıdır" (Supreme Court, 2021: 31). Yüksek Mahkeme, hem iş mahkemesinin, hem de temyiz mahkemesinin kararları doğrultusunda, Uber sürücülerinin "işçi”" olarak sınıflandırılmasını ve başta iş ve sosyal güvenlik 
hukukundan doğan ekonomik ve sosyal haklarının sağlanması gerekliliğine karar vermiştir.

Uber sürücülerinin "işçi” olarak sınıflandırılmasına yönelik bir diğer karar ise Fransa'da verilmiştir. Uber sürücüsü, Ekim 2016 - Nisan 2017 tarihleri arasında Uber için yolculuk taleplerini yerine getirmiş, ancak Uber sürücüsünün Nisan 2017 tarihinde profilinin devre dişı bırakılmasının ardından, geçmişe dönük sınıflandırmanın yapılması, fazla çalışma ücreti, hafta tatili ücreti ve kıdem ve ihbar tazminatı için Uber'e dava açmıştır (Vadekkethil, 2020). Bu dava 2020 yllında Fransız Yargıtayı tarafindan karara bağlanmıştır.

Fransiz Yarg1tay1 (The French Court of Cassation), Uber sürücülerinin yolculuk koşullarını, ücretlerini ve güzergâhlarını belirleme yetkilerinin olmamasına ve belirli düzeyde yolculuk taleplerinin reddedilmesi durumunda ise profillerin devre dışı bırakılmasına özellikle dikkat çekmiştir. Bu bağlamda, yukarıda ifade edilen tüm bu unsurların, Uber ile sürücüler arasında kurulan ilişkinin bir iş ilişkisinin varllı̆ına işaret ettiğini belirterek, sürücülerin "serbest meslek (selfemployment)" olarak sinıflandırılmasının ise "gerçekçi olamayacağına" karar vermiştir (French Court of Cassation, 2020).

\section{Uber Sürücülerinin Sendikalaşma, Toplu Sözleşme ve Grev Hakkı Mücadelesi}

Gig ekonomisi platformları, işleri parçalayarak ve işgücünü kutuplaştırıp esnek bir yapıda tutarak, sendikalaşmayı önlemeye yönelik bir iş organizasyonu inşa etmeyi hedeflemektedir. Ancak, platformlar tarafindan inşa edinmek istenen iş̧ organizasyonuna, platformlarda yer alan işçiler tarafından zaman içinde işçi protestoları yükselmekte ve çeşitli mücadele araçları ile karşılık verilmektedir (Tassinari ve Maccarrone, 2020; Woodcock ve Graham, 2020). Gig işçilerinin, görünmeyen algoritmalar aracıllğıyla denetlenmesi, güvencesiz istihdam yapıs1, düşük ücret politikasının egemen kılınması, uzun çalışma saatlerini içermesi ve duygusal emek sorununu ortaya çıkarması, küresel ölçekte meydana gelen işçi protestolarının başlıca nedenleri arasında yer aldığı bilinmektedir. Bu bağlamda, hem yerel düzeyde faaliyet göstermesi, hem de yoğun bir işgücüne sahip olmas1, Uber sürücülerinin başta sendikalaşma girişimlerini ve protesto eğilimlerini hızlandırmaktadır. $\mathrm{Bu}$ doğrultuda, Uber sürücülerinin çalışma koşullarının düzeltilmesi, sendikalaşma hakkının tanınması ve işçi olarak sınıflandırılmalarına yönelik pek çok kentte ve ülkede grevlerin ve protestoların düzenlediği bilinmektedir.

Uber sürücülerinin ücret kesintileri, çalışma koşulları ve düşük gelir politikasına karşı, 2014 yılından itibaren ABD'nin çeşitli eyaletlerinde yürüttükleri mücadeleler güçlenerek devam etmektedir. Örneğin, 2014 yllı Eylül ayında yolculuk ücretlerinin düşürülmesine ve ücret kesinti oranlarındaki artış kararına yönelik, New York'ta gerçekleşen greve (Uber uygulamasını kapatma biçiminde) yaklaşık 1000 sürücü katılmıştır. Uber sürücüleri, ücret politikasında ve diğer konularda 
yapılan tek taraflı değişikliklerin geri alınmasını talep etmişlerdir. Sürücülerin gerçekleştirmiş olduğu grev sonrası, Uber, ücret başta olmak üzere diğer değişiklik kararlarını geri çekmek zorunda kalmıştır (Griswold, 2014; Aloisi, 2016: 681-682; Collier vd., 2017: 16).

Uber'e yönelik yapılması planlanan, ancak hedeflenen düzeye ulaşmayan grev örneği ise 2016 yıllındaki "Süper Bowl-5010" etkinliğidir. Uber sürücüleri, kış aylarında düşen yolculuk ücretlerinin ve taleplerinin düzeltilmesi ${ }^{11}$ için 7 Şubat 2016 tarihinde düzenlenecek "Süper Bowl-50" etkinliğinde greve gitme kararı almışlardır (Close, 2016). Ancak, gerçekleştirilmesi planlanan grev başarıya ulaşamamıştır. Collier ve arkadaşları, "Süper Bowl-50" grevinin etkili olamamasını ise iki büyük etkene bağlamaktadır. Bir yandan, planlanan uygulama kapatma şeklindeki greve, bölgedeki Uber sürücülerinin bilgilendirilmesinin yetersizliğinden dolay1 kitlesel katılımın sağlanamamas1, diğer yandan Uber'in, "Süper Bowl-50" etkinliği için bölgedeki sürücülere yüksek saatlik ücretler taahhüt etmesi ve algoritmalar aracıllğıyla diğer bölgelerdeki sürücüleri etkinliğin olduğu bölgeye çekme yönünde girişimde bulunması grevin başarısızlıkla sonuçlanmasına yol açmıştır (Collier vd., 2017: 16). Bu bağlamda, "Süper Bowl-50" grevi hem sürücüler arasındaki iletişim kopukluğu nedeniyle kitlesellik kazanamamış, hem de Uber'in ücret politikası ve algoritmalar aracıllğıyla yönlendirilen sürücülerin katılım göstermesi nedeniyle başarısızlığa uğramıştır.

Bir diğer örnek ise, 2018 yllı Ekim ayında Hindistan'ın Mumbai ve Delhi şehirlerinde gerçekleşmiştir. Petrol fiyatlarda yaşanan artış sonrası giderlerini karşılayamayan Uber ve Uber'in Hindistan yerel uygulaması olan Ola sürücüleri grev karar1 ilan etmiştir (Shah, 2018). Her iki platform sürücülerinin, Uber ve Ola'dan başlıca talepleri ise; çalışma koşullarının düzeltilmesi ve petrol fiyatlarındaki artış sonrası daha da düssen gelirlerinin telafi edilmesine yöneliktir (Woodcock ve Graham, 2020: 156). Bu doğrultuda, 22 Ekim 2018 tarihinde başlayan greve yaklaşık 28 bin sürücünün (Economist, 2018) katıldığ1 ve fasılalarla olmak üzere yaklaşık 2 ay sürdüğü bilinmektedir (Sen, 2019). Uber ve Ola sürücülerinin almış oldukları grev kararında ön plana çıkan iki önemli özellik ise, hem sürücülerinin katılım oranlarının yüksek olması (yüzde 90), hem de kesintili de olsa uzun sürmesidir. Böylece, Uber ve Ola sürücülerinin, platformlara karşı yoğun bir mücadele yürütmeleri politika yapıcıların da dikkatini çekmiş ve düzenleme girişimleri yoğunlaşmıştır (Minchin, 2020).

Uber sürücülerinin "işçi”" olarak sınıflandırılmaması, sürücülerin sendikalaşma hakkını engellediği de bilinmektedir. Ancak, ABD'de AFL-CIO'ya

10 Amerikan Ulusal Futbol Ligi final maçı.

11 Uber sürücülerinin,"Süper Bowl-50”"etkinliğinin gerçekleştirileceği günde grev karar1 almalarının esas nedeni, yaklaşık 800 bin şehir sakini yanında etkinliğe tahminen 300 bin kişinin katılacak olmasıdır. Böylece, Uber sürücüleri bir yandan hizmet akışını durdurma yoluyla Uber karşısında pazarlık gücünü kendi lehine çevirmeyi amaçlarken, diğer yandan da taleplerinin daha geniş kitlelere ulaşması hedeflemişlerdir (Goodfellow, 2016). 
bağlı New York Taksi İşçileri Sendikası (NYTWA), İngiltere'de Genel İşçi Sendikası (GMB), Hindistan'da "Uygulama Tabanlı Ulaşım İşçileri Sendikası" (IFAT) ve Güney Afrika'da SATAWU, Uber sürücülerini yasal statülerinden bağımsız olarak örgütleme çalışması yürütmektedir (ITF, 2019; GMB, 2021). NYTWA, GMB ve IFAT, öncelikli olarak, Uber sürücülerinin yasal çerçevede "işçi” olarak nitelendirilmeleri ve çalışma koşullarının düzeltilmesi için mücadele yürütmektedir (Collier vd., 2017: 17; Johnston ve Land-Kazlauskas, 2019: 3).

Küresel ölçekte Uber'e yönelik gerçekleştirilen en geniş katılımlı grev ise 2019 y1lında gerçekleşmiştir. Uber’in borsada halka arz edileceği gün olan 8 Mayıs 2019 tarihinde NYTWA tarafindan organize edilen ve İngiltere, Brezilya, Kanada ve Avustralya'daki sürücülerin de katıldığı büyük çaplı bir grev organize edilmiştir (Bussewitz, 2019; Conger vd., 2019). Uber sürücülerinin gerçekleştirdiği bu grev, daha iyi bir gelir elde edilmesi ve çalışma koşullarının düzeltilmesi amacını taşımaktadır. Nitekim Uber sürücülerinin ülkeler arasındaki talepleri de birbirine oldukça benzer konuları içermektedir. Örneğin, Kanadaki Uber sürücüleri, "saatlik en az 18 dolar veya harcamalar dâhil 16 dolar garanti" ücret talep ederken, Birleşik Krallıktaki Uber sürücüleri ise - GMB sendikas1 -, ücretlerin "mil başına 1,25 sterlin'den 2 sterline" çıkarılmasını, sürücüler tarafindan Uber'e ödenen komisyon ücretinin "yüzde 25 'ten yüzde 15 'e düşürülmesini, haksız işten çıkarmaların sona" erdirilmesini ve asgari ücret ve diğer hakların sağlanmasını talep etmişlerdir (Kollewe, 2019).

Uber sürücülerinin dünyanın farklı bölgelerinde, aynı tarihte ve benzer ortak talepler doğrultusunda gerçekleștirdiği "8 Mayıs" grevi, esasen iki açıdan oldukça önemlidir. Öncelikli olarak, Uber'in sürücüler üzerinde kurmak istediği bask1, sürücüler tarafından tersine çevrilmiş ve karşılaştıkları sorunlara yönelik işçi protestoları yoğunluk kazanmışır. İkinci olarak, Uber sürücüleri hem yerel düzeyde, hem de dünyanın pek çok farklı bölgesinde ortak taleplerini birlikte dile getirilebileceğini, örgütlenebileceğini ve greve çıkabileceğini platformlara göstermiştir. Bu bağlamda, çalışma yaşamına yönelik ortak taleplerin belirlenebilmesi, birlikte hareket edilebilmesi ve mücadeleye tüm bileşenlerinin katılım gösterebilmesi büyük önem taşımaktadır. Böylece, platformda meydana gelen iş ilişkisinin düzenlenmesini ortak çerçevede gerçekleştirecek ve tüm gig işçilerini kapsayacaktır.

\section{Sonuç}

Yirminci yüzyllın son çeyreğinden günümüze uz̧anan süreçte, işgücü piyasasında sermaye lehine politikaların yoğunlaşttğı, teknoloji alanında devrimsel gelişmelerin ivme kazandığı ve emeği metalaştırıc1 eğilimlerin hızlandığı gözlenmektedir. 2008 küresel ekonomik krizi sonrası bırakınız yapsınlar bırakınız geçsinler düşüncesinin yeniden egemen hale gelmesi ve işsizlikteki artıs platform hizmetlerine olan talebi arttırırken gig ekonomisinin hızla yaygınlaşmasına da zemin hazırlamıştır. 
Gig ekonomisinin hızlı büyümesi dünya genelinde sosyal ilişkileri, tüketimi, çalışmanın anlamını ve iş ilişkilerini yeniden biçimlendirmektedir. Gig ekonomisinin niteliği ve bu anlamda yarattığ yeni iş ilişkisi, çalışma koşulları, ücret politikası, sosyal güvenlik hakk1, sendikalaşma ve toplu sözleşme hakkı gibi konuları tamamen platformların insafına bırakmaktadır. Bu durum, küresel ölçekte dibi doğru yanısı hızlandırmaktadır.

Gig ekonomisinde gerçekleşen iş ilişkisinin yasal çerçevede düzenlenmeden yaygınlık kazanması taraflar arasında eşit sonuçlar doğurmamaktadır. Bu eşitsizliğin temelinde, platformların kendilerini işveren olarak değil, arz ile talebi buluşturan teknoloji şirketi olarak tanımlaması ve işgücünü bilinçli bir şekilde "bağımsız yüklenici" olarak sınıflandırması yatmaktadır. Bu durum, gig firmalarına çalışma yaşamını ilgilendiren yasal sorumluluklarından kaçınma fırsatı sağlarken, gig işçilerine sosyo-ekonomik risklere karşı koruyucu düzenlemelere erişimlerini büyük ölçüde engellemektedir. Böylece gig ekonomisi, emeğin metalaşmasını hızlandırmakta ve iş ilişkilerini derinden bozmaktadır.

Gig ekonomisi gerek yerel düzenleyiciler, gerek uluslararası düzenleyiciler için birçok zorluk yaratmaktadır. Özellikle, platformlarda yer alan işgücünün sinıflandırma sorunu ülkeler arasında farklı uygulamaların ve kararların ortaya çıkmasına yol açmaktadır. Bu farklılıklar, işgücü piyasasında bir yandan yenilik, girişimcilik ve esneklik, diğer yandan çalışma koşullanı, gelir ve sosyal güvenlik yaklaşımları arasındaki güç ilişsileri etrafında şekillenmektedir. Gig işçilerinin sınıflandırma sorununa yönelik yapılacak yeni düzenlemeler taraflar arasındaki güç ilişkisine ve sosyo-ekonomik risklerin taraflar arasındaki dağılımına dikkat edilerek gerçekleştirilmesi büyük önem taşımaktadır. Aksi takdirde, işgücü piyasasında kuralsızlaştırmanın ve güvencesizliğin daha da şiddetlenmesine yol açacaktır.

Gig ekonomisi içinde en bilinen platform olan Uber'in kısa bir zaman aralı̆̆ında küresel ölçekte yaygınlaşarak işgücünü genişletmesi pek çok yeni sorunu da beraberinde getirmiştir. Bu anlamda, çalışmaya konu olan Uber sürücülerinin çalışma koşullarında, sınıflandırma davalarında ve sendikalaşma girişimlerinde ortaya çıkan sorunlar, çözüme ilişkin süreçleri hızlandırmıştır. Uber, komisyon ücretini arttırmak ve sosyo-ekonomik hakları ödemekten kaçınmak amaciyla, sürücüleri bilinçli bir şekilde yanlış sınıflandırmakta, taleplerini kabul etmeyen ülkelerden (Danimarka ve Kolombiya) ise çekilmektedir. Uber'in mevcut işgücünün yolculuk kabul oranlarını arttırmak için uyguladığı doğrudan ve dolaylı stratejiler, sürücülerin yoğun denetime tabi tutulmasına neden olmaktadır. Uber bir yandan sürücülerini algoritmalar aracilğ̆1yla tek taraflı kontrol etmekte, gözetim altında tutmakta, bilinçli şekilde yanlış sınıflandırmakta diğer yandan ise iş ile ilgili giderlere karışmama politikasını benimsemektedir. Buna karşlık, sürücüler hem iş mahkemelerinde açtıkları sınıflandırma davalarıyla hukuki mücadelelerini sürdürmekte, hem de sendikalar/dernekler altında örgütlenerek protesto ve grev gibi mücadele araçları ile inşa edilmek istenen yeni iş organizasyonuna karşı direnmektedir. Uber sürücülerinin $\mathrm{ABD}$, Güney Afrika ve Belçika mahkemelerinde 
açılan sınıflandırma davalarında verilen bağımsız yüklenici kararlarına yönelik İngiltere Yüksek Mahkemesi'nin ve Fransız Yargitay'ının Uber sürücülerini bağımsız yüklenici olarak değil, işçi olarak nitelendirme kararı, diğer ülkelerdeki sürücüler için önem taşımaktadır. Nitekim diğer ülkelerdeki Uber sürücülerinin bireysel ve/veya temsilcileri (sendikalar/dernekler) aracillğıyla iş mahkemelerinde açlacak sınıflandırma davalarında, İngiltere ve Fransa yüksek mahkemelerinin vermiş oldukları kararların önemli bir içtihat oluşturması beklenmektedir. Kanun yapıcıların çalışma yaşamını ilgilendiren düzenlemeleri ABD'deki Prop-22 oylamasında olduğu gibi bireysel tercihlere bırakmaması ve işçi sendikalarının bu gibi girişimlere karş1 yoğun bir mücadele yürütmesi oldukça önemlidir. Aksi takdirde, çalışma yaşamını ilgilendiren düzenlemelerin tüketici tercihlerine sunulması, zaman içinde çalışanların mevcut haklarının geriye yürütülmesine ve ciddi hak kayıplarına yol açacaktır. 


\section{KAYNAKÇA}

Airbnb. (2021). What are Airbnb Service Fees?, https://www.airbnb.co.uk/help/article/1857/what-are-airbnb-service-fees (Erişim Tarihi: 15.02.2021).

Aloisi A. (2016). Commoditized Workers. Case Study Research on Labour Law Issues Arising from a Set of 'On-Demand/Gig Economy' Platforms. Comparative Labor Law \& Policy Journal, 37 (3), 663-690.

Anwar, M. A. ve Graham, M. (2020). Between a rock and a hard place: Freedom, flexibility, precarity and vulnerability in the gig economy in Africa. Competition \& Change. Doi: 10.1177/1024529420914473

Anwar, M. A., ve Graham, M. (2020). Hidden Transcripts of the Gig Economy: Labour Agency and the New Art of Resistance Among African Gig Workers. Environment and Planning A: Economy and Space, 52 (7), 1269-1291.

Arın, T. (2013). Kriz, Devlet, İktisat ve Sosyal Güvenlik Politikaları. İstanbul: İstanbul Bilgi Üniversitesi Yayınları.

Aykaç, A. (2018). Dayanışma Ekonomileri. İstanbul: Metis.

Bajwa, U. vd., (2018). Towards an Understanding of Workers' Experiences in the Global Gig Economy. Global Migration \& Health Initiative, Toronto.

Ballotpedia. (2021). California Proposition 22, App-Based Drivers as Contractors and Labor Policies Initiative (2020)

https://ballotpedia.org/California_Proposition_22,_App-

Based_Drivers_as_Contractors_and_Labor_Policies_Initiative_(2020)

(Erişim Tarihi: 15.02.2021).

Benach, J, Vives, A, Amable, M, Vanroelen, C, Tarafa, G, Muntaner, C. (2014). Precarious

employment: understanding an emerging social determinant of health. Annu Rev Public Health, 35 (1), 229-253.

Berry, M. (2021). How many Uber Drivers are there?,

https://therideshareguy.com/how-many-uber-drivers-are-there/ (Erişim Tarihi: 4.03.2021).

Bussewitz, C. (2019). Montreal drivers join global Uber strike over 'poverty wages', https://montrealgazette.com/news/local-news/citing-poverty-wagesrideshare-drivers-strike-ahead-of-uber-ipo (Erişim Tarihi: 31.03.2021).

Burawoy, M. (2015). Üretim Siyaseti: Kapitalizm Ve Sosyaližmde Fabrika Rejimleri. İstanbul: NotaBene Yayınları.

Carter, S.M. (2018). Over half of Americans delay or don't get health care because they can't afford it-these 3 treatments get put off most, https://www.cnbc.com/2018/11/29/over-half-of-americans-delay-healthcare-becasue-they-cant-afford-it.html (Erişim Tarihi: 10.01.2021).

Casetext, (2021). O'Connor v. Uber Techs., Inc.

https://casetext.com/case/oconnor-v-uber-techs-inc-32 (Erişim Tarihi: 12.02.2021). 
Chen, M. (2020) Yeni Bir Isşci Dünyası: Gig Ekonomisiyle Yü̈leşmek, Der: Panitch, L., Albo, G. Socialist Register 2020: Pazar Distopyasının Ötesinde. (Çev. Ersin Vedat Güler, 121-140), İstanbul: Notabene Yayınları.

Close, K. (2016). Uber Drivers Plan to Strike During Super Bowl 50, https://time.com/4207739/uber-drivers-strike-super-bowl/ (Erişim Tarihi: 30.03.2021).

Conger, K. vd., (2019) Uber Drivers' Day of Strikes Circles the Globe Before the Company's I.P.O.,

https://www.nytimes.com/2019/05/08/technology/uber-strike.html, (Erişim Tarihi: 31.03.2021).

Collier, R. B., Dubal, V. B., \& Carter, C. (2017). Labor Platforms and Gig Work: The Failure to Regulate.

Cornelissen, J., ve Cholakova, M. (2019). Profits Uber everything? The Gig Economy and the Morality of Category Work. Strategic Organization, 1- 10.

Court of Appeals. (2018). O'CONNOR V. UBER, https://cdn.ca9.uscourts.gov/datastore/opinions/2018/09/25/14-16078.pdf (Erişim Tarihi: 11.02.2021).

Cranford, C. Vosko L, F. ve Zukewich N. (2003). Precarious Employment In The Canadian Labour Market: A Statistical Portrait, Just Labour, 3, 6-22.

De Stefano, V. M. (2016a). The Rise of the 'Just-in-Time Workforce': On-Demand Work, Crowd Work and Labour Protection in the 'Gig-Economy'. Comparative Labor Law and Policy Journal, 37 (3), 471-504.

De Stefano, V. M. (2016b). Introduction: Crowdsourcing, The Gig-Economy, Comparative Labor Law and Policy Journal, 37(3), 461-470.

De Stefano, V. M. (2018). The Gig Economy And Labour Regulation: An International And Comparative Approach. Law J. Soc. \& Lab. Rel., 4, 68-78.

Deon, L., (2020). Regulating the Scope of Employment in the Gig Economy: Towards Enhanced Rights at Work in the Age of Uber. LSE Law Review, 5, 190-208.

Dunn, M. (2018). Making Gigs Work: Career Strategies, Job Quality and Migration İn The Gig Economy. (Yayınlanmamış Doktora Tezi). Kuzey Karolina Üniversitesi

Dokko, J. vd.,(2015). Workers and the Online Gig Economy. The Hamilton Project, 1-8.

Donovan, S. A. vd.,(2016): What Does The Gig Economy Mean For Workers. Congressional Research Service (CRS Report R44365). Washington.

Economist. (2018). Mumbai unions force Uber and Ola into a corner, https://www.economist.com/business/2018/11/03/mumbai-unions-forceuber-and-ola-into-a-corner (Erişim Tarihi: 30.03.2021).

European Commission (2016) A European Agenda for the Collaborative Economy. Brussels: European Commission. 
European Parliament (2017) European Parliament Resolution of 15 June 2017 on a European Agenda for the Collaborative Economy (2017/2003(INI)). Brussels: European Parliament. Available http://www.europarl.europa.eu/doceo/document/TA-8-2017-

0271_EN.html?redirect (Erişim Tarihi 03.02.2021)

European Parliament. (2020), The Platform Economy And Precarious Work. Luxembourg: European Parliament. Erişim Adresi https://www.europarl.europa.eu/RegData/etudes/STUD/2020/652734/IP OL_STU(2020)652734_EN.pdf (Erişim Tarihi 03.12.2020)

Eurofound. (2018), Digital Age: Platform Work: Types and Implications for Work and Employment-Literature Review, Eurofound-Working Paper, Erişim Adresi https://www.eurofound.europa.eu/sites/default/files/wpef18004.pdf (Erişim Tarihi 23.12.2020)

Erdut, T. (1998). Yeni Teknolojilerin İs İliskileri Üzerine Etkileri, Ankara: Türk Ağır Sanayii ve Hizmet Sektörü Kamu İşverenleri Sendikası

Erdut, T. (2005). İşgücü Piyasasında Enformelleşme ve Kadın İşgücü. Çalı̧̧ma ve Toplum Dergisi, 3(6), 11-49.

Erdut, T. (2021). Dijitalleşme ve İşgücü Piyasası. Karatabta İs Yazৃlar Dergisi, 19, 2559.

Erdut, Z. (2004). Liberal Ekonomi Politikaları ve Sosyal Politika. Calssma ve Toplum Dergisi, 2,11-37.

Erdut, Z. (2007). Enformel İstihdamin Ekonomik, Sosyal ve Siyasal Etkileri. Calsma ve Toplum Dergisi, 4 (12), 53-82.

ETUC. (2021). National rulings on platform work show need for EU action, https://www.etuc.org/en/pressrelease/national-rulings-platform-work-showneed-eu-action (Erişim Tarihi: 10.03.2021).

Flanagan, F. (2019). Theorising the Gig Economy and Home-Based Service Work. Journal of Industrial Relations, 61(1), 57-78.

Fishman, S. (2019). Working For Yourself (11. Baskı). Berkeley, California: Nolo

Friedman, G. (2014). Workers Without Employers: Shadow Corporations and the Rise of the Gig Economy. Review of Keynesian Economics, 2 (2), 171-188.

Gandini A (2018) Labour Process Theory and the Gig Economy. Human Relations, 72 (6), 1039-1056.

GMB. (2021). Historic workers' rights win: Supreme Court rules in Uber drivers' favour, https://www.gmb.org.uk/news/uber-workers-rights-historic-gmbsupreme-court-drivers-legal-battle (Erişim Tarihi: 30.03.2021).

Goodfellow, J. (2016). San Francisco may grind to a halt over Super Bowl weekend if planned Uber strike goes ahead, https://www.thedrum.com/news/2016/02/06/san-francisco-may-grind-haltover-super-bowl-weekend-if-planned-uber-strike-goes/(Erişim Tarihi: 30.03.2021). 
Graham, M. ve Woodcock, J. (2018), 'Towards a Fairer Platform Economy: Introducing the Fairwork Foundation', Alternate Routes: A Journal of Critical Social Research, 29, 242-253.

Graham, M. vd.,(2017), Digital Labour and Development: Impacts of Global Digital Labour Platforms and the Gig Economy on Worker Livelihoods, Transfer: European Review of Labour and Research, 23 (2), 135-162.

Greer, I. (2016). Welfare Reform, Precarity and the Re-Commodification Of Labour. Work, Employment And Society, 30 (1), 162-173.

Griswold, A. (2014). Uber Just Caved on a Big Policy Change After Its Drivers Threatened to Strike, https://slate.com/business/2014/09/uber-drivers-strikethey-protested-cheap-uberx-fares-uber-backed-down.html (Erişim Tarihi: 30.03.2021).

Harris, S. D., ve Krueger, A. B. (2015). A Proposal for Modernizing Labor Laws for Twenty-First-Century Work: The "Independent Worker" Hamilton Project Washington.

Harvey, D. (2015). Neoliberalizm Kısa Taribi (Çev. A. Onacak). (2. Baskı). İstanbul: Metis Yayınları.

Harvey, D. (2019). Postmodernliğin Durumu Kültürel Değişimin Kökenleri (S. Savran, Çev.). (8. baski). İstanbul: Metis Yayınları.

Heiland, H. (2021) Controlling Space, Controlling Labour? Contested Space in Food Delivery Gig Work. New Technology, Work and Employment. 1-15.

Huws, U. (2014). Labor in the Global Digital Economy: The Cybertariat Comes Of Age. NYU Press.

Huws U., vd., (2017) Work in the European gig economy: research results from the UK, Sweden, Germany, Austria, the Netherlands, Switzerland and Italy, Brussels and Hatfield, European Foundation for Progressive Studies, UNI Europa and University of Hertfordshire.

HyreCar. (2021). Can You Drive For Both Uber and Lyft?, https://www.hyrecar.com/blog/drive-for-both-uber-and-lyft/ (Erişim Tarihi: 18.02.2021).

ILO, (2020). World Employment and Social Outlook Trends 2020, Geneva: ILO.

ILO, (2021). ILO Gözlem: COVID-19 ve Çalısma Yaşam,, 7. Baskisı. https://www.ilo.org/wcmsp5/groups/public/---europe/---ro-geneva/---iloankara/documents/briefingnote/wcms_769693.pdf (Erişim Tarihi: 18.02.2021)

Internet World Stats. (2021). World Internet Usage And Population Statistics, https://www.internetworldstats.com/stats.htm (Erişim Tarihi: 10.2.2021).

Internet World Stats. (2021a). Internet Users Statistics for Africa, https://www.internetworldstats.com/stats1.htm (Erişim Tarihi: 11.2.2021).

Isaac, M. ve Scheiber, N. (2016). Uber Settles Cases With Concessions, but Drivers Stay Freelancers, https://www.nytimes.com/2016/04/22/technology/ubersettles-cases-with-concessions-but-drivers-stay-freelancers.html (Erişim Tarihi: 11.02.2021). 
Isaac M. ve Scheiber N. (2016a). Uber to Pay at Least $\$ 84 \mathrm{~m}$ in Settlement, https://www.bostonglobe.com/business/2016/04/21/uber-settles-caseswith-concessions-but-drivers-stayfreelancers/aiPzORifjk3YVCkSqjDybL/story.html (Erişim Tarihi: 11.02.2021).

ITF; International Transport Workers' Federation, (2021). Indian Federation of App-based Transport Workers launched in Mumbai, https://www.itfglobal.org/en/news/indian-federation-app-based-transportworkers-launched-in-mumbai (Erişim Tarihi: 31.03.2021).

ITU; International Telecommunication Union (2021). ICT Prices, https://www.itu.int/en/ITU-

D/Statistics/Documents/statistics/2020/PercentIndividualsUsingInternet.xls $\mathrm{x}$ (Erişim Tarihi: 10.2.2021).

ITUC. (2019). 2019 ITUC GLOBAL RIGHTS INDEX The World's Worst Countries For Workers. [URL: https://www.ituc-csi.org/IMG/pdf/2019-06ituc-global-rights-index-2019-report-en-2.pdf]

Jessop, B. (2005). Hegemonya, Post-Fordizm ve Küreselleşme Ekseninde Kapitalist Devlet (Çev: B. Yarar ve A. Özkazanç), İstanbul: İletişim Yayınları

Johnston H. ve Land-Kazlauskas C. (2018) Organizing On-Demand: Representation, Voice, and Collective Bargaining in the Gig Economy, Geneva, International Labour Office

Kalleberg, A. L. (2009). Precarious Work, Insecure Workers: Employment Relations In Transition. American Sociological Review, 74(1), 1-22.

Kalleberg, A. L. ve Dunn, M. (2016). Good Job, Bad Jobs in the Gig Economy. Perspectives on Work, 10-14.

Kässi, O., ve Lehdonvirta, V. (2018). Online labour index: Measuring the Online Gig Economy for Policy and research. Technological Forecasting And Social Change, 137, 241-248.

Katta, S vd., (2020). (Dis) Embeddedness and (De) Commodification: COVID-19, Uber, and the Unravelling Logics of the Gig Economy. Dialogues in Human Geography, 10 (2), 203-207

Khreiche, M. (2018). Milieus In The Gig Economy (Yayınlanmamış Doktora Tezi). Virginia Tech Üniversitesi, Politeknik Enstitüsü.

Kollewe, J. (2019). Uber drivers strike over pay and conditions, https://www.theguardian.com/technology/2019/may/08/uber-drivers-

strike-over-pay-and-conditions, (Erişim Tarihi: 31.03.2021).

Koray, M. (2018). Sosyal Politika, Ankara: İmge Kitabevi Yayınları.

Larsson, A., ve Sabolova, D. (2019). Gig Patients. The Digital Transformation of Labor, 174-184.

Lehdonvirta V, vd.,(2019). The Global Platform Economy: A New Offshoring Institution Enabling Emerging-Economy Microproviders. Journal of Management 45(2): 567-599. 
Legislative Analyst's Office, (2020), Proposition 22, https://lao.ca.gov/ballot/2020/Prop22-110320.pdf (Erişim Tarihi: 10.02.2021).

Lobel, O. (2017). The Gig Economy \& The Future of Employment and Labor Law. University of San Francisco Law Review, Forthcoming.

Lyons, H. (2021). Belgian union wants a Brussels taxi app to solve Uber issue https://www.brusselstimes.com/news/belgium-all-news/157932/belgiumunion-wants-a-brussels-taxi-app-to-solve-uber-issue-criticises-sven-gatzpascal-smet-vervoort/ (Erişim Tarihi: 10.03.2021)

Mahnkopt, B. (2020) Digital Kapitaližm Çăğnda Işsin Geleceği, Der: Panitch, L., Albo, G. Socialist Register 2020: Pazar Distopyasının Ötesinde. (Çev. Eren Buğlalılar, 105-120), İstanbul: Notabene Yayınları.

Manriquez, M. (2019). Work-games in the gig-economy: a case study of Uber drivers in the city of Monterrey, Mexico. In Work and Labor in the Digital Age. Emerald Publishing Limited.

Minchin, J. (2020).Ola and Uber face new regulations in India, https://www.intelligenttransport.com/transport-news/112231/ola-and-uberface-new-regulations-in-india/ (Erişim Tarihi: 30.03.2021).

MTurk. (2021). Pricing, https://www.mturk.com/pricing (Erişim Tarihi: 15.02.2021).

Munck, R. (2013). The Precariat: A View from the South. Third World Quarterly 34 (5):747- 762 .

Munck, R.(2002). Labour and Globalisation: The New Great Transformation Zed Books.

Muntaner, C. (2018). Digital Platforms, Gig Economy, Precarious Employment, and the İnvisible Hand Of Social Class. International Journal of Health Services, 48 (4), 597-600.

O'Brien, S.A. (2020) Prop. 22: After \$200 million California brawl, Uber and Lyft's gig worker fight is far from over, https://www.mercurynews.com/2020/11/16/prop-22-after-200-millioncalifornia-brawl-uber-and-lyfts-gig-worker-fight-is-far-from-over/(Erişim Tarihi: 10.02.2021).

Öngen, T. (2004): Sermayenin Yeni Hegemonya Stratejileri, I. Ulusal Sosyal Politika Kongresi, 22- 24 Ocak, Ankara, s. 246- 253.

Özuğurlu, M. (2008). Anadolu'da Küresel Fabrikanın Doğuşu: Yeni İşçilik Örüntülerinin Sosyolojisi. İstanbul: Kalkedon Yayınlar1.

Özveri, M. (2013). Türkiye'de Toplu Ișs Sözlesmesi Yetki Sistemi ve Sendikasizlaştrma (1963-2009), Ankara Üniversitesi Siyasal Bilgiler Fakültesi Sosyal Politika Araştırma ve Uygulama Merkezi, Ankara: Legal Yayıncilık.

Pershan, C. (2016). Uber Protest Less Disruptive Than Imagined With Just 200 Of 1,500 Expected Drivers, https://sfist.com/2016/02/02/uber_drivers_disrupt_uber_with_prot/ (Erişim Tarihi: 30.03.2021). 
Purcell, C., \& Brook, P. (2020). At Least I'm My Own Boss! Explaining Consent, Coercion and Resistance in Platform Work. Work, Employment and Society, 1-16.

Ravenelle, A. J. (2019). Hustle and Gig: Struggling and Surviving in the Sharing Economy. California: Univ of California Press.

Risak, M. (2017). Fair Working Conditions For Platform Workers. Friederich Ebert Stiftung.

Rodgers, G. (1989) Precarious Work in Western Europe: The State of the Debate. In: Rodgers G and Rodgers J (eds.) Precarious Jobs in Labour Market Regulation: The Growth of Atypical Employment in Western Europe. Geneva: International Institute for Labour Studies; Free University of Brussels.

Schor, J. (2016). Debating the sharing economy. Journal of Self-Governance and Management Economics, 4(3), 1-15. Erişim Adresi:

https://greattransition.org/images/Schor-Debating-Sharing-Economy.pdf (Erişim Tarihi: 20.11.2020)

Scheiber, N. (2017). How Uber Uses Psychological Tricks to Push Its Drivers' Buttons, https://www.nytimes.com/interactive/2017/04/02/technology/uberdrivers-psychological-tricks.html. (Erişim Tarihi: 10.02.2021).

Schmidt, F.A. (2017). Digital Labour Markets In The Platform Economy: Mapping The Political Challenges of Crowd Work and Gig Work. Friedrich-Ebert-Stiftung.

Schwab, K. (2016), The Fourth Industrial Revolution, World Economic Forum. Geneva.

Schwellnus, C., vd., (2018), Gig Economy Platforms: Boon Or Bane ?, OECD Economics Department Working Paper,

Sen, S. (2019). Ola, Uber drivers threaten fresh strike for better earnings, https:/ / timesofindia.indiatimes.com/city/mumbai/ola-uber-drivers-threatenfresh-strike-for-better-earnings/articleshow/67506814.cms (Erişim Tarihi: 30.03.2021).

Shah, A. (2018). Uber, Ola drivers strike in India, demanding higher fares, https://www.reuters.com/article/us-uber-ola-strike-idUSKCN1MW1WZ (Erişim Tarihi: 30.03.2021).

Siddiqui, F. (2020). Uber and Lyft must make their drivers in California full employees, judge rules, https://www.washingtonpost.com/technology/2020/08/10/uber-lyftab5/(Erişim Tarihi: 10.02.2021).

Supreme Court. (2021), Uber BV and others (Appellants) $v$ Aslam and others (Respondents). Erişim Adresi: https://www.supremecourt.uk/cases/docs/uksc2019-0029-judgment.pdf (Erişim Tarihi 25.02.2021)

Stanford J. (2017) The Resurgence of Gig Work: Historical and Theoretical Perspectives, The Economic and Labour Relations Review, 28 (3), 382-401.

Stewart, A., \& Stanford, J. (2017). Regulating work in the gig economy: What are the options?. The Economic and Labour Relations Review, 28(3), 420-437. 
TakeLesson. (2021). Are there any fees associated with your service?, https://support.takelessons.com/hc/en-us/articles/202972603-Are-thereany-fees-associated-with-your-service- (Erişim Tarihi: 15.02.2021).

Tassinari, A., ve Maccarrone, V. (2020). Riders on the Storm: workplace solidarity among gig Economy couriers in Italy and the UK. Work, Employment and Society, 34(1), 3554.

Temiz, H. E. (2004) Eğreti İstihdam: İşgücü Piyasasında Güvencesizliğin ve İstikrarsızlığın Yeni Yapılanması, Callşma ve Toplum Dergisi, 2, 55-80.

The Brussels Times. (2017). Uberpop: the Uber taxi service is taken to court in Brussels, https://www.brusselstimes.com/brussels/45581/uberpop-the-ubertaxi-service-is-taken-to-court-in-brussels/ (Erişim Tarihi: 10.03.2021).

The French Court of Cassation. (2020). UBER, www.courdecassation.fr/IMG/20200304_arret_uber_communique_eng.pdf (Erişim Tarihi: 28.03.2021).

Todoli-Signes, A. (2017). The 'Gig Economy': Employee, Self-Employed or the Need For A Special Employment Regulation?. Transfer: European Review of Labour and Research, 23 (2), 193-205.

Uber. (2021). Payments and Earnings, https://www.uber.com/gh/en/drive/basics/tracking-your-earnings/ (Erişim Tarihi: 15.02.2021).

Uber. (2021a). Use Uber in cities around the World https://www.uber.com/global/en/cities/ (Erişim Tarihi: 1.03.2021).

Uber. (2021b). Company Info, https://www.uber.com/enGB/newsroom/company-info/ (Erişim Tarihi: 1.03.2021).

Vadekkethil, A. C. (2020). French Court of Cassation Rules that Uber Drivers are Employees, https://ohrh.law.ox.ac.uk/french-court-of-cassation-rules-thatuber-drivers-are-employees / (Erişim Tarihi: 27.03.2021).

Vallas, S. P. (2019). Platform Capitalism: What's At Stake For Workers?. New Labor Forum 28 (1), 48-59.

Vallas, S., ve Schor, J. B. (2020). What do platforms do? Understanding the gig economy. Annual Review of Sociology, 46, 273-294.

Yahoo Finance. (2021). Uber Technologies, Inc. (UBER) https:// finance.yahoo.com/quote/UBER. (Erişim Tarihi: 1.03.2021)

Webster J. (2016) Microworkers of the Gig Economy: Separate and Precarious, New Labor Forum, 25 (3), 56-64.

Wong, J.C. (2016). Uber reaches $\$ 100 \mathrm{~m}$ settlement in fight with drivers, who will stay contractors

https://www.theguardian.com/technology/2016/apr/21/uber-driver-

settlement-labor-dispute-california-massachusetts (Erişim Tarihi: 12.02.2021).

Wordspy. (2021) Of Gigs and Gags,

https://wordspy.com/blog/category/etymology/ (Erişim Tarihi: 9.12.2020).

Woodcock, J., ve Graham, M. (2020). The Gig Economy. London: Polity Press. 
Wood, A. J., vd., (2019a). Networked but Commodified: The (Dis) Embeddedness of Digital Labour in the Gig Economy. Sociology, 53 (5), 931-950.

Wood, A. vd., (2019b). Good Gig, Bad Gig: Autonomy and Algorithmic Control in the Global Gig Economy. Work, Employment and Society, 33 (1), 56-75.

Wu, Q., vd., (2019). Labor Control in the Gig Economy: Evidence from Uber in China. Journal of Industrial Relations, 61(4), 574-596.

Zabçı, F. Ç. (2002). Dünya Bankası'nın Küresel Pazar İçin Yeni Stratejisi: Yönetişim. Ankara Üniversitesi SBF Dergisi, 57 (3), 151-179.

Zwick, A. (2018). Welcome to the Gig Economy: Neoliberal Industrial Relations and the Case of Uber. GeoJournal, 83 (4), 679-691. 